\title{
Does Inflation Targeting Anchor Long-Run Inflation Expectations? Evidence from Long-Term Bond Yields in the U.S., U.K., and Sweden
}

\author{
Refet S. Gürkaynak \\ Bilkent University \\ Andrew T. Levin \\ Federal Reserve Board \\ and \\ Eric T. Swanson \\ Federal Reserve Bank of San Francisco \\ March 2006 \\ Working Paper 2006-09
}

http://www.frbsf.org/publications/economics/papers/2006/wp06-09bk.pdf

The views in this paper are solely the responsibility of the authors and should not be interpreted as reflecting the views of the Federal Reserve Bank of San Francisco or the Board of Governors of the Federal Reserve System. 


\title{
Does Inflation Targeting Anchor Long-Run Inflation Expectations? Evidence from Long-Term Bond Yields in the U.S., U.K., and Sweden*
}

\author{
Refet S. Gürkaynak $^{* *}$, Andrew T. Levin ${ }^{* *}$, and Eric T. Swanson ${ }^{* *}$
}

\begin{abstract}
We investigate the extent to which inflation targeting helps anchor long-run inflation expectations by comparing the behavior of daily bond yield data in the United Kingdom and Sweden-both inflation targeters - to that in the United States, a non-inflation-targeter. Using the difference between far-ahead forward rates on nominal and inflation-indexed bonds as a measure of compensation for expected inflation and inflation risk at long horizons, we examine how much, if at all, far-ahead forward inflation compensation moves in response to macroeconomic data releases and monetary policy announcements. In the U.S., we find that forward inflation compensation exhibits highly significant responses to economic news. In the U.K., we find a level of sensitivity similar to that in the U.S. prior to the Bank of England gaining independence in 1997, but a striking absence of such sensitivity since the central bank became independent. In Sweden, we find that forward inflation compensation has been insensitive to economic news over the whole period for which we have data. Our findings support the view that a well-known and credible inflation target helps to anchor the private sector's perceptions of the distribution of long-run inflation outcomes.
\end{abstract}

Keywords: inflation targeting, inflation compensation, excess sensitivity, forward rates, high-frequency data JEL Codes: E31, E52, E58.

March 1, 2006

\footnotetext{
* In compiling the data for this project, we received invaluable assistance from Jan Alsterlind, Andrew Clare, Lars Hörngren, Michael Joyce, Peter Lildholt, and Lena Stromberg. We thank Jesper Lindé for providing code to generate impulse responses for a New Keynesian small open economy model calibrated to Sweden. The paper has also benefited from very helpful discussions, comments, and suggestions from Paul Beaudry, Alan Blinder, Mick Devereux, Ken Kuttner, Rick Mishkin, Scott Roger, Brian Sack, Klaus Schmidt-Hebbel, Eric Parrado, Lars Svensson, Jonathan Wright, and seminar participants at the Swedish Riksbank, the International Monetary Fund, Johns Hopkins University, UC Berkeley, the European Central Bank, Università Bocconi/IGIER, Bilkent University, the Federal Reserve Board, and the NBER Monetary Economics Program Meeting. We appreciate the excellent research assistance of Andrew Marder, Claire Hausman, and Oliver Levine. The views expressed in this paper are solely those of the authors, and do not necessarily reflect the views of the Board of Governors of the Federal Reserve System, the management of the Federal Reserve Bank of San Francisco, or any other person associated with the Federal Reserve System.

** Gürkaynak: Dept. of Economics, Bilkent University, Ankara, Turkey, refet@bilkent.edu.tr. Levin: Division of Monetary Affairs, Federal Reserve Board, Washington, DC, levina@frb.gov. Swanson: Economic Research, Federal Reserve Bank of San Francisco, San Francisco, CA, eric.swanson@sf.frb.org.
} 


\section{Introduction}

Long-term price stability is a central goal of monetary policy for essentially every modern central bank. ${ }^{1}$ To facilitate the achievement of this objective, a number of countries around the world have adopted an "inflation targeting" framework, in which a numerical objective for the level of inflation in a few years' time is explicitly stated, vigorously pursued, and clearly communicated to the public in the form of periodic, detailed reports on the current and projected future state of the economy, particularly inflation (see, e.g., Bernanke, Laubach, Mishkin, and Posen, 1999). ${ }^{2}$ The adoption of inflation targeting has been encouraged by a growing body of literature that finds the framework to offer advantages in terms of the formulation, implementation, and communication of monetary policy (e.g., Walsh, 1995, Svensson, 1997). ${ }^{3}$

Nevertheless, empirical analysis has yielded at best weak support for the notion that inflation targeting (IT) significantly influences the behavior of inflation. In particular, monthly or quarterly inflation rates and short-term inflation forecasts have not behaved very differently in IT and non-IT economies, with all of the major industrial nations experiencing significant disinflation in the 1990s (e.g., Ball and Sheridan, 2004, Gertler, 2004), ${ }^{4}$ while analysis of longer-term inflation expectations (e.g., Levin and Piger, 2004) has been hampered by a scarcity of data due to the relatively recent adoption of IT in most countries and the low, typically semiannual, frequency of surveys that measure long-term expectations.

In this paper, we evaluate the influence of inflation targeting on long-term inflation expectations by comparing the behavior of daily bond yield data in the United States, the United Kingdom, and Sweden. We focus on these three countries in particular because all three have had a range of inflation-indexed government bonds outstanding for several years, providing us with good

\footnotetext{
${ }^{1}$ In other periods, of course, one can find many instances in which a central bank's primary objective was to provide the government with cheap credit and seigniorage revenue.

${ }^{2}$ See also Leiderman and Svensson (1995), Bernanke and Mishkin (1997), and Kuttner (2005).

${ }^{3}$ See also Persson and Tabellini (1993), McCallum (1996), Bernanke et al. (1999), and Svensson and Woodford (2003).

${ }^{4}$ See also Bernanke et al. (1999) and Johnson (2002). Also, Ertürk and Özlale (2005) examine the effects of inflation targeting in emerging markets as well as in industrialized economies using a GARCH framework.
} 
measures of forward real as well as nominal interest rates. ${ }^{5}$ Forward inflation compensation — the difference between forward rates on nominal and inflation-indexed bonds_-provides us with a high-frequency measure of the compensation investors demand to cover expected future inflation and the risks associated with that inflation at a given horizon. ${ }^{6}$ Thus, if 10 -year-ahead forward inflation compensation is relatively insensitive to incoming economic news, then that would suggest that financial market participants have fairly stable views regarding the distribution of long-term inflation outcomes, and hence that the monetary policy framework has been reasonably successful in anchoring long-term inflation expectations.

In contrast to previous empirical studies of inflation targeting, the daily frequency of our bond yield data together with the frequent release of important macroeconomic statistics and monetary policy announcements enables us to obtain relatively precise estimates of the impact of these releases on far-ahead forward inflation compensation, even for samples that span only the past seven to ten years - the period for which inflation-indexed bonds have been traded in the U.S. and Sweden and the length of time since Sweden and many other countries adopted IT. While previous empirical work has been limited to quarterly or even semiannual data over a five- to tenyear period, we are able to bring to bear over three thousand daily observations of the response of long-term bond yields to major economic news releases in the U.S., U.K., and Sweden.

Our analysis reveals substantial cross-country differences in the sensitivity of forward nominal interest rates and inflation compensation to economic news. For the United States, we find that far-ahead forward nominal rates and inflation compensation have exhibited highly significant responses to important economic announcements. Moreover, these responses are systematic in the sense that they are consistent with financial markets perceiving some degree of

\footnotetext{
${ }^{5}$ In ongoing research, we are working to extend the methods of this paper to other inflation targeting countries. However, the data limitations for other countries are often severe: for example, New Zealand has only one inflationindexed bond outstanding, which makes the computation of forward rates impossible. Canada has only one inflationindexed bond until 1996 and only two from 1996 to 2001, and even these bonds have extremely long durations (30 years) and low liquidity, making implied forward rates difficult to estimate and noisy. High-frequency data on market forecasts of macroeconomic statistical releases in Australia, New Zealand, and Finland are not available, to our knowledge. Finally, data in developing countries with inflation targets, such as South Africa and Chile, tends to be even more limited.

${ }^{6}$ In contrast to yields, the use of forward rates avoids any direct influence from short-term developments, thereby permitting a sharper focus on inflation expectations at a particular horizon. See section 2, below.
} 
(or some chance of) pass through from inflation in the near term to inflation at very long horizons. For the United Kingdom, we find very similar results to those for the U.S. prior to the Bank of England gaining independence in mid-1997, but after Bank of England independence, we find that far-ahead forward nominal rates and inflation compensation in the U.K. have been invariant with respect to economic news. Finally, far-ahead forward nominal rates and inflation compensation in Sweden have been unresponsive to economic news over the whole period for which we have data. These findings support the view that a well-known and credible inflation target helps to anchor the private sector's perceptions of the distribution of long-run inflation outcomes.

Importantly, our analysis of the inflation compensation implicit in long-term bond yields does not rely on the expectations theory of the term structure. In particular, risk premia on longterm bonds could vary greatly over time and still not impact our estimates so long as that variation occurs primarily at lower, business-cycle frequencies rather than from one day to the next. Empirical evidence regarding the failure of the expectations hypothesis indeed has been primarily at these lower frequencies (see, e.g., Cochrane and Piazzesi, 2005). Nevertheless, we discuss the robustness of the interpretation of our results with respect to time-varying risk premia in Section 5.

Of course, one interpretation of our findings is that it is not changes in the mean of the distribution of long-run inflation outcomes that are responsible so much as changes in the variance, skewness, or other moments of that distribution. In fact, this view is entirely consistent with the conclusions that we draw, namely that inflation targeting helps to anchor market perceptions of the entire distribution of future long-run inflation outcomes.

The remainder of the paper proceeds as follows. Section 2 presents impulse response functions from two empirically calibrated New Keynesian dynamic stochastic general equilibrium (DSGE) models to serve as benchmarks for comparison to our subsequent empirical results. Section 3 describes our daily data and how we compute forward nominal and real interest rates, inflation compensation, and the surprise components of macroeconomic data releases and monetary policy announcements. Section 4 investigates the sensitivity of far-ahead forward interest rates and inflation compensation in the U.S., U.K., and Sweden to economic news. Section 5 discusses 
possible interpretations of our results and provides additional sensitivity analysis. Section 6 concludes. A Data Appendix presents a detailed description of all the data used in our analysis.

\section{Benchmark Closed and Open-Economy New Keynesian Models}

To aid in the interpretation of our empirical findings, it is useful to have results from a standard benchmark macroeconometric model for comparison. In this paper, we present results from two such models in order to encompass both the U.S., a relatively closed economy, and the U.K. and Sweden, which are relatively more small and open economies.

For a benchmark closed economy model, we use the New Keynesian DSGE model of Christiano, Eichenbaum, and Evans (2005). Highlights of the model include monopolistic competition and staggered price-setting in both goods and labor markets, habit persistence in consumption, adjustment costs in investment, indexation of prices and wages to past inflation, and hump-shaped and persistent impulse response functions to shocks that match very closely those found in U.S. data. See Christiano et al. (2005) for details of the model, parameter values, and their estimation procedure. $^{7}$

For a small open economy model, we use the small New Open Economy (New Keynesian DSGE) model of Adolfson, Laséen, Lindé, and Villani (forthcoming). The basic equations of the model are very similar to those of Christiano et al. (2005) and Altig, Christiano, Eichenbaum, and Lindé (2005), except that Adolfson et al. extend the model to include a large foreign economy that is treated by the small home economy as a given, exogenous VAR. Adolfson et al. estimate the

\footnotetext{
${ }^{7}$ Christiano et al. (2005) do not explicitly model the central bank’s monetary policy reaction function (they use a reduced-form Wold representation for monetary policy instead), so we close the model with a Taylor-type policy rule:$$
i_{t}=(1-c)\left[r^{*}+(1+a) \bar{\pi}_{t}+b y_{t}\right]+c i_{t-1}+\varepsilon_{t}^{i}
$$

where $i$ is the one-period nominal interest rate, $r^{*}$ is the reciprocal of the representative household's discount factor, $\bar{\pi}$ is the trailing four-quarter moving average of inflation, $y$ the deviation of output from steady state, and $\varepsilon$ an i.i.d. shock. We use the values of $a, b$, and $c$ estimated by Rudebusch (2002) for the period 1987Q4 to 1999Q4: $a=.53$, $b=.93$, and $c=.73$. Note that the policy rule is both "backward-looking," in that the interest rate responds to current values of output and inflation rather than their forecasts, and "inertial," in that it includes the lagged federal funds rate. Both of these features add inertia to the short rate, which gives the model the best possible chance of explaining the term structure evidence we find below.
} 
model using Bayesian methods applied to Swedish data—see their paper for details of the model, parameter values, and the estimation procedure. ${ }^{8}$

Together, these two models serve as useful benchmarks for our analysis. Although we do not present results here for a model explicitly calibrated to the U.K., that economy may be thought of as an intermediate case between the larger and more closed U.S. and the smaller and more open Sweden.

In Figure 1, we present impulse response functions for the short-term nominal interest rate to each of three typical shocks: an output-demand shock, an inflation-cost-push shock, and a monetary policy shock. The output-demand shock is an exogenous, one-period shock to government purchases in each model, financed by lump-sum taxation, that raises output by $1 \%$ on impact. The inflation-cost-push shock is an exogenous, one-period shock to the disutility of labor that raises the aggregate inflation rate by 1 percentage point on impact. The monetary policy shock is an exogenous, one-period shock to the central bank's interest rate rule that raises the short-term nominal interest rate by 1 percentage point on impact. The hump-shaped impulse responses of the two models to these shocks are very standard and match key features of the data in all three countries - the U.S., U.K., and Sweden — that we study in our empirical analysis below.

We do not review here the impulse responses of all 10-20 variables in the models to the three shocks above- see the original papers cited above for details of this type. Instead, we focus on two key observations to take away from Figure 1. First, short-term interest rates in the models return essentially all of the way to steady state within about five years and certainly within ten years after each shock. This observation is not specific to the two models we have considered here, but rather is typical of a wide variety of macroeconomic models in which the steady-state levels of inflation and the real interest rate are constant over time and perfectly known by all agents. ${ }^{9}$ It

\footnotetext{
${ }^{8}$ Adolfson et al. (forthcoming) include a monetary policy reaction function in their model which is very similar to the one we use for the closed-economy model —in particular, the rule is both backward-looking and inertial—-thus, we keep their model exactly as is when generating the impulse responses below. Matlab code for generating impulse response functions in the model was provided to us by Jesper Lindé.

${ }^{9}$ Note that this observation remains valid even when some variables in the model are nonstationary (as in the Adolfson et al. (forthcoming) and Altig et al. (2005) models), such as productivity, output, and employment, so long as the
} 
follows that, in these models, expectations of short-term nominal interest rates far enough in the future should remain relatively fixed after a shock.

This brings us to the second key observation to draw from Figure 1: namely, that it is not long-term interest rates that should remain stable after an economic shock, but rather far-ahead forward interest rates that should remain stable. The long-term interest rate in the models is essentially an average of short-term interest rates over the lifetime of the long-term bond, and this should be expected to respond somewhat to economic shocks to the extent that short-term rates in the near future move.

Thus, we will focus our empirical work below on the behavior of far-ahead forward interest rates after major economic announcements. The benchmark models above suggest that these announcements should have little or no effect on forward interest rates so long as those rates are sufficiently far ahead.

interest rate rules in these models respond to variables like the output gap and inflation gap (deviations from steady state), which are stationary. 
Figure 1

\section{Interest Rate Impulse Responses in Two Benchmark Macroeconomic Models}

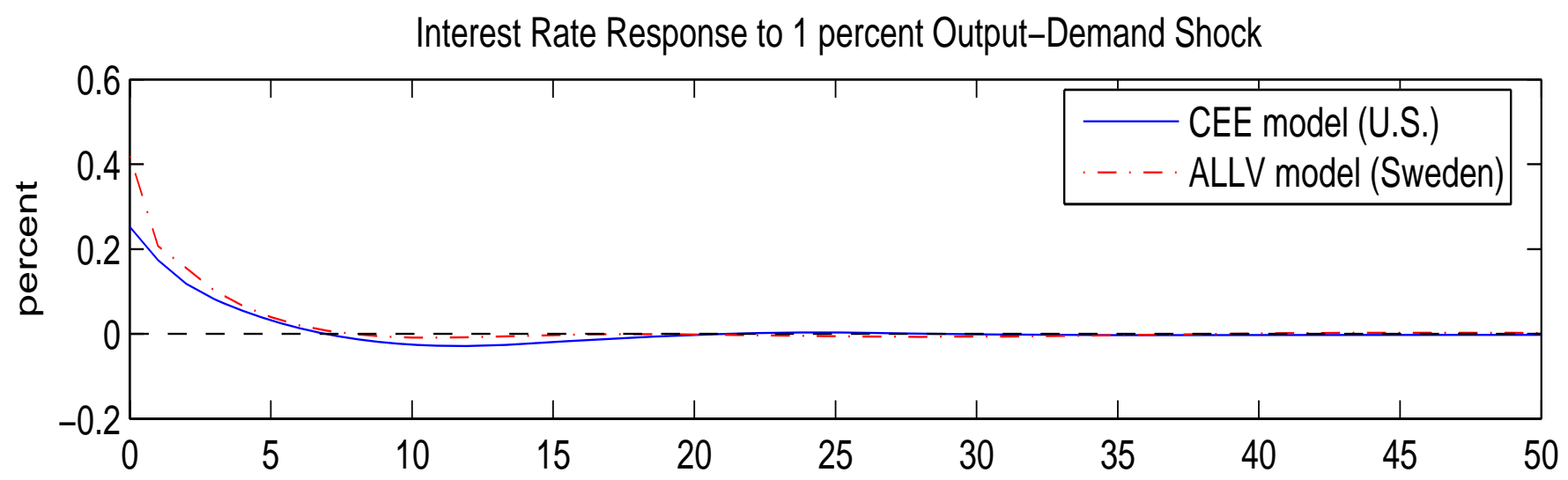

Interest Rate Response to 1 percent Inflation-Cost-Push Shock

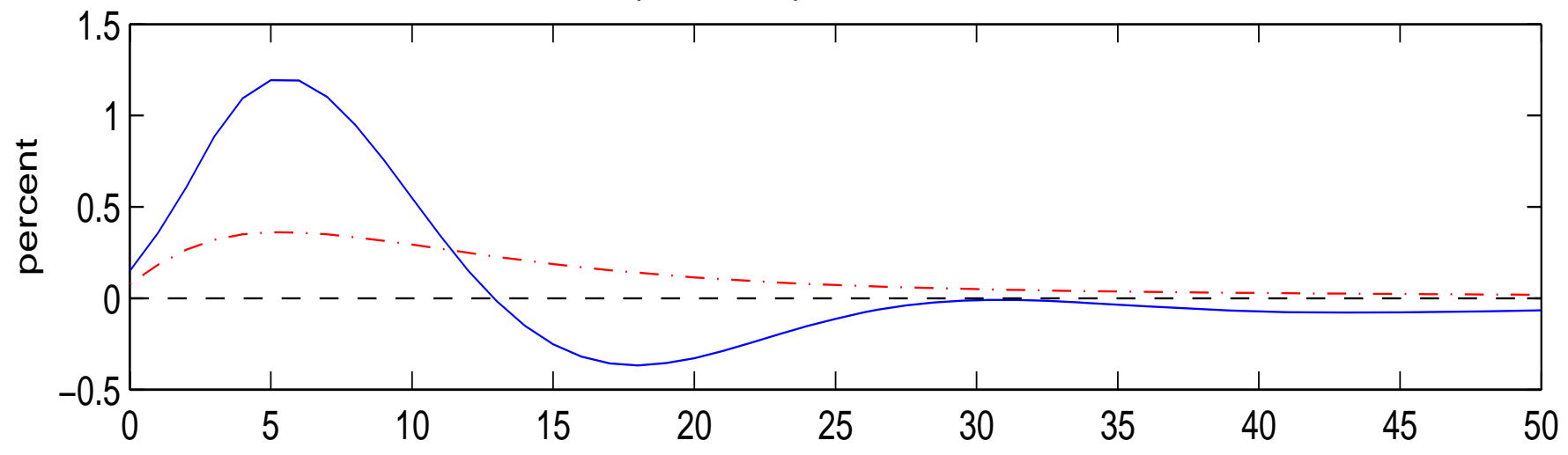

Interest Rate Response to 1 percent Monetary Policy Shock

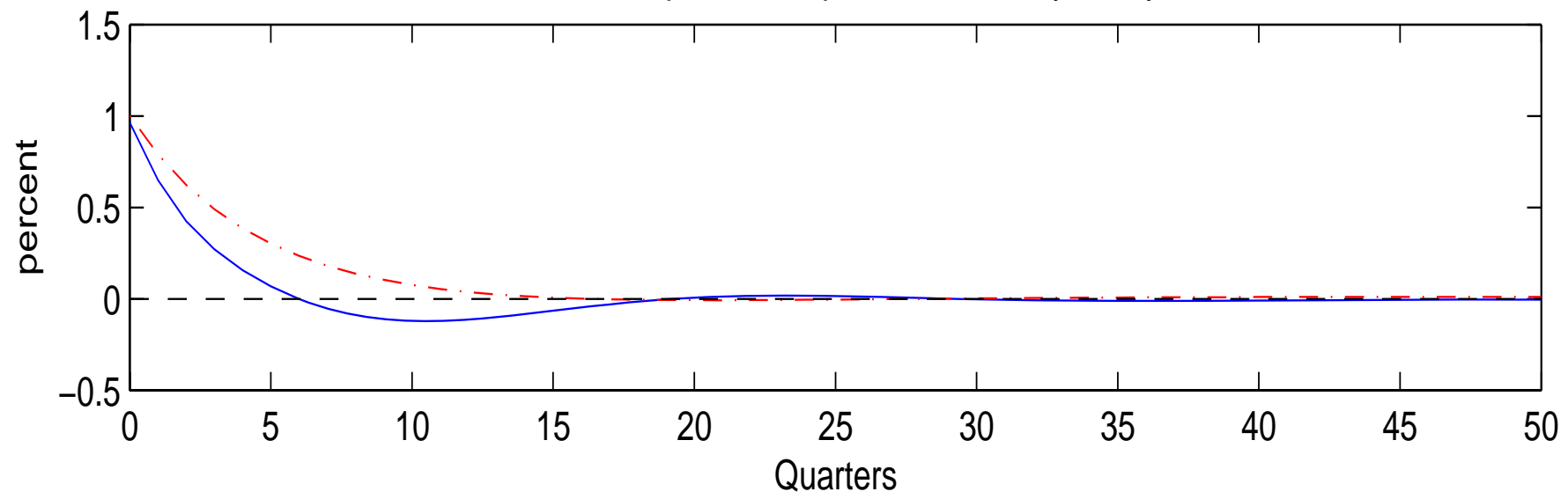

Note: “CEE model” is the closed-economy New Keynesian DSGE model estimated by Christiano et al. (2005) to fit U.S. data. "ALLV model” is the small-open-economy New Keynesian DSGE model estimated by Adolfson et al. (2006) to fit Swedish data. The "output-demand shock" is a shock to government purchases financed by lump-sum taxation sufficient to raise output by 1 percent on impact. The "inflation-cost-push shock” is a shock to households' marginal disutility of work sufficient to raise inflation by 1 percent on impact. The "monetary policy shock" is a shock to the monetary policy rule sufficient to raise the short-term nominal interest rate by 1 percent on impact. See text for details. 


\section{Methods and Data}

To investigate whether far-ahead forward interest rates and inflation compensation in the U.S., U.K., and Sweden respond systematically to macroeconomic data releases and monetary policy announcements, we run a series of high-frequency event-study regressions of the form:

$$
\Delta y_{t}=\alpha+\beta X_{t}+\varepsilon_{t}
$$

where $t$ indexes days, $\Delta y_{t}$ is the change in the forward interest rate or inflation compensation over the day, $X_{t}$ is the surprise component of the macroeconomic data releases and monetary policy announcements that took place that day, and $\varepsilon_{t}$ is a residual representing the influence of other factors on the change in $y_{t}$ that day.

\subsection{Forward Interest Rates and Forward Inflation Compensation}

As discussed in section 2, to study the extent to which inflation expectations are firmly anchored at longer horizons, we must look beyond the effects of economic news over the first few years and focus instead on the behavior of forward interest rates and inflation compensation several years ahead.

Forward rates are often a very useful means of interpreting the term structure of interest rates. For a bond with a maturity of $m$ years, the yield $r_{t}^{(m)}$ represents the rate of return that an investor requires to lend money today in return for a single payment $m$ years in the future (for the case of a zero-coupon bond). By comparison, the $k$-year-ahead one-year forward rate $f_{t}^{(k)}$ represents the rate of return from period $t+k$ to period $t+k+1$ that the same investor would require to commit at time $t$ to a one-year loan beginning at time $t+k$ and maturing at time $t+k+1$. The linkage between these concepts is simple: an m-year zero-coupon security can be viewed as a sequence of one-year forward agreements over the next $m$ years. The $k$-year-ahead one-year forward rate $f_{t}^{(k)}$ can thus be obtained from the yield curve by the simple definition: ${ }^{10}$

\footnotetext{
${ }^{10}$ If we observed zero-coupon yields directly, computing forward rates would be as simple as this. In practice, however, most government bonds in the U.S. and abroad make regular coupon payments and thus the size and timing of the coupons must be accounted for to translate observed yields into the implied zero-coupon yield curve. We show
} 


$$
1+f_{t}^{(k)}=\frac{\left(1+r_{t}^{(k+1)}\right)^{k+1}}{\left(1+r_{t}^{(k)}\right)^{k}}
$$

In our empirical analysis, for the U.S., we use data on nominal and real forward rates on U.S.

Treasury securities produced by the Federal Reserve Board. For the U.K., we use data on nominal and real forward rates on U.K. government securities produced by the Bank of England and made available on their web site. For Sweden, we obtained data on nominal and inflation-indexed Swedish government yields from the Swedish Riksbank. ${ }^{11}$ Having obtained forward nominal rates and forward real rates for each country, we define forward "inflation compensation" to be the forward nominal rate less the forward real rate at each horizon. Note that this measure captures the compensation that investors demand both for expected inflation and for the risks or uncertainty associated with that inflation at each horizon.

Given our interest in measuring long-term expectations, we focus our analysis on the longest maturity for which we have high-quality data for both real and nominal bond yields. The exceptional liquidity, depth, and breadth of the markets for government securities near the ten-year horizon thus suggests focusing on the one-year forward rate from nine to ten years ahead (i.e., the one-year forward rate ending in ten years). As we showed in the previous section, this horizon is sufficiently far out for standard macroeconomic models to essentially return to steady state, so that

below that U.S. Treasury STRIPS data yield essentially identical results. Note also that our yield curve data for the U.S., U.K., and Sweden is all quoted on a continuously-compounded basis, which implies that our forward rate data is given by $f_{t}^{(k)}=(k+1) r_{t}^{(k+1)}-k r_{t}^{(k)}$ rather than equation (3.1), which is for annually-compounded yields.

${ }^{11}$ The Federal Reserve Board computes implied zero-coupon yields from off-the-run U.S. Treasury yields using the extension of the Nelson-Siegel (1987) method described in Svensson (1994) and Gürkaynak, Sack, and Wright (2005). U.S. inflation-indexed bonds (TIPS) were issued for the first time in January 1997 and only annually in the first few years after that date, so our far-ahead forward real rate data for the U.S. begins in January 1998. Although the Federal Reserve Board provides a full estimated real yield curve only back to January 1999, we extend the 9-to-10 year forward rate series back to January 1998 by taking the 9- and 10-year TIPS rates and computing the implied forward rate between the two using the Shiller-Campbell-Schoenholtz (1983) approximation. The Bank of England computes implied zero-coupon nominal and real yields from observed U.K. government yields using a spline-based procedure (details are available from the Bank of England's web site), with daily data available back to 1985 . For Sweden, we backed out the implied zero-coupon yield curves and forward rates using the Svensson (1994) methodology (which was designed for Swedish data and is the same method employed by the Federal Reserve Board for U.S. data) and checked that these did in fact fit the Swedish bond data very well. The first inflation-indexed Swedish government bond was issued in March 1994, but additional indexed bonds were not issued until May 1996, when a range of four new maturities were issued, so our forward real rate data for Sweden begin in May 1996. 
any movements in forward interest rates or inflation compensation at these horizons are very difficult to attribute to transitory responses of the economy to a shock.

\subsection{Macroeconomic Data Releases}

Financial markets are forward-looking, so the expected component of macroeconomic data releases should have essentially no effect on interest rates. ${ }^{12}$ To measure the effects of macroeconomic data releases on interest rates, then, we must first compute the unexpected, or surprise, component of each release. Using the surprise component of the releases also removes any issues of endogeneity arising from interest rates feeding back to the macroeconomy, because any such effects, to the extent that they are predictable, will be incorporated into market expectations for the release.

To measure the surprise component of each data release in our sample, we compute the difference between the actual release and the median forecast of that release made by professional forecasters just a few days prior to the event. For the U.S. and U.K., we obtained data on professional forecasts of the next week's statistical releases for around fifty macroeconomic time series for each country collected and published every Friday by Money Market Services (MMS). ${ }^{13}$ However, not all of these statistics have a significant impact on interest rates, even at the short end of the yield curve. Thus, to conserve space and reduce the number of exogenous variables in our regressions, we restrict attention to only those macroeconomic variables that have statistically significant effects on the spot one-year Treasury bill rate in those countries. Note that this selection procedure does not bias our estimates of the sensitivity of far-ahead forward interest rates to economic news because those interest rates are insensitive to all macroeconomic and monetary policy announcements under the null hypothesis. Our results below are very similar when we include all available variables on the right-hand side of the regression.

\footnotetext{
${ }^{12}$ Kuttner (2001) tests and confirms this hypothesis for the case of monetary policy announcements.

13 The quality of the MMS data as measures of expectations has been verified by previous authors-see, e.g., Balduzzi et al (2001) and Andersen et al. (2003).
} 
In contrast to the U.S. and U.K., data on professional forecasts is more limited for Sweden. Thus, for that country we use all of the available professional forecast data collected by Bloomberg Financial Services every week. ${ }^{14}$

Additional details regarding the macroeconomic data releases and professional forecast data for all of these countries are included in the Data Appendix at the end of this paper.

\subsection{Monetary Policy Announcements}

As with macroeconomic data releases, we must compute the surprise component of monetary policy announcements in each country in order to measure the effects of these announcements on interest rates. Rather than use the median of professional forecasts to measure expectations, however, we use the one-day change in a short-term interest rate, such as a 3-month government bill rate, around each monetary policy announcement to measure the surprise component of the announcement. The advantage of using market-based measures of monetary policy surprises is that they are of higher quality and are available essentially continuously—see, for example, Krueger and Kuttner (1996) and Gürkaynak, Sack, and Swanson (2002).

For the U.S., we measure monetary policy surprises using the change in the current-month federal funds future contract on the dates of Federal Reserve monetary policy announcements, as in Kuttner (2001). ${ }^{15}$ For the U.K. and Sweden, we do not have futures data for the policy rates of the corresponding central banks, so we measure monetary policy surprises using the change in the spot 3-month U.K. government bill rate on the days of Bank of England monetary policy announcements and the change in the 3-month Swedish government bill rate on the days of Riksbank monetary policy announcements. The change in the 3-month rate on these days reflects changes in financial market expectations about the current and future course of monetary policy

\footnotetext{
${ }^{14}$ Bloomberg offers forecasts of a greater number of Swedish statistics than Money Market Services and were more readily available to us. For the U.S. and U.K., the Bloomberg forecast data does not go back as far as the MMS data (about 1996 for Bloomberg vs. 1985 for MMS-US and 1993 for MMS-UK), but the two data sources agree very closely when they overlap.

${ }^{15}$ We have verified that using the 1-day change in the 3-month U.S. Treasury Bill rate to measure the surprise component of U.S. monetary policy announcements does not alter our findings. We stick with federal funds futures as the preferred measure for the U.S. because that is the most common in the literature and because Gürkaynak, et al. (2002) showed that, among the many possible financial market instruments that potentially measure U.S. monetary policy expectations, federal funds futures are the most accurate in a forecasting sense.
} 
over the subsequent 3 months —-while this is not the same as the shorter horizon one would obtain from a very near-term futures contract, it is nonetheless an excellent measure of the change in the near-term monetary policy environment. Additional details regarding these announcements and financial market measures of the surprise component of these announcements are provided in the Data Appendix at the end of this paper.

\section{Results}

\subsection{The Sensitivity of U.S. Nominal Interest Rates to Economic News}

In Table 1, we report the results for regression (3.1) applied to nominal interest rates in the United States. Each column reports the results from a regression of daily changes in the corresponding interest rate on the surprise component of the major economic announcements listed at the left. We restrict attention in the regressions to only those days on which some macroeconomic statistic was released or a monetary policy announcement was made, but our results are not sensitive to this restriction. Note that, although there are more than one thousand daily observations in each of these regressions on which some major economic announcement was made, most of those observations for any individual regressor are zero because any given macroeconomic statistic is only released once per month (or once per quarter in the case of GDP, once per week in the case of Initial Claims). We begin the sample in February 1994 because there was a structural break in the method of U.S. monetary policy announcements at that time, but our results are not sensitive to this starting point—see, for example, Gürkaynak, Sack, and Swanson (2005) for results from a similar regression for the U.S. beginning in 1990.

To aid in interpreting our coefficient estimates, each macroeconomic surprise is normalized by its standard deviation, so that the coefficients in the table report the interest rate response in basis points per standard deviation surprise in the corresponding macroeconomic statistic — the one 
exception to this rule is for monetary policy surprises, which we leave in basis points, so that those coefficients represent a basis point per basis point response. ${ }^{16}$

As a benchmark, the first column of Table 1 reports the responsiveness of the spot one-year U.S. Treasury rate to our macroeconomic and monetary policy announcements. Not surprisingly, we find that this short-term interest rate responds to these announcements with an overwhelming degree of statistical significance - the $p$-value for the joint hypothesis that all of the coefficients are equal to zero, excepting the constant and dummy variables, is below machine precision. Moreover, the responses we estimate are all consistent with what one would expect from a Taylor-type reaction function for monetary policy: i.e., upward surprises in inflation, output, or employment lead to increases in short-term interest rates, and upward surprises in initial jobless claims or unemployment (two countercyclical economic indicators) cause short-term interest rates to fall. The magnitudes of the coefficients imply that a two-standard-deviation surprise typically leads to a 2 to 9 bp change in the 1-year rate, depending on the statistic. Although these magnitudes might seem small at first, they are in fact not surprising given the relatively high volatility of the monthly data releases, which implies that the signal-to-noise ratio of any single announcement for the true underlying level of economic activity and rate of inflation tends to be relatively low. Also in line with this observation is the fact that the regression $R^{2}$ is only .16 , implying that even on those days when we know the major economic news that day, there are enough subtleties in the announcement and its context and enough other factors influencing Treasury yields that the regression explains only one-sixth of the variation in short-term rates. ${ }^{17}$ Nevertheless, the high statistical significance of many of the individual coefficients and the regression as a whole imply that the releases we consider do contain information that is very relevant for the behavior of short-term interest rates, with signal-to-noise ratios that are clearly non-negligible.

\footnotetext{
${ }^{16}$ Each regression also includes a constant, a "Y2K" dummy that takes on the value 1 on the first business day of 2000, and a year-end dummy that takes on the value 1 on the first business day of any year. These coefficients are not reported to save space and because we generally found them to be relatively unimportant in our regressions.

${ }^{17}$ For example, the CPI release includes not just the top-line inflation numbers, but also a detailed breakdown of inflation by product category. Markets may respond differently to a given headline number depending on the underlying detail of the release and whether that detail suggests the news in the release is transitory or more permanent. Our professional forecast data covers only the top-line number. The situation is very similar for GDP and indeed all of the other macroeconomic statistics we consider.
} 
A final observation to take away from the short-rate regression in Table 1 is that monetary policy surprises lead to about a 1-for-4 response of the one-year yield to the federal funds rate, consistent with the view that a surprise change in the funds rate is generally not a complete surprise to markets, but rather a bringing forward or pushing back of policy changes that were expected to have had a high probability of occurring in the future, anyway. ${ }^{18}$

In the middle column of Table 1, we begin to investigate the central question of the paper, looking at the sensitivity of far-ahead forward interest rates to economic news. If ten years is a sufficient length of time for the U.S. economy to return essentially to steady state following an economic shock and if long-term inflation expectations are firmly anchored in the U.S., then one might expect to see little or no response of these far-ahead forward interest rates to economic news. As can be seen in the middle column of Table 1, this is clearly not the case: ten-year-ahead forward nominal rates respond significantly — and often very highly so — to seven of the eleven macroeconomic announcements in the table, and the joint hypothesis that all of the coefficients in the regression are zero is rejected with a $p$-value below $10^{-7}$. Moreover, the signs and magnitudes of these coefficients are not random, but rather closely resemble those from the previous columnthe one exception to this rule is monetary policy announcements, for which the estimated effect on far-ahead forward nominal interest rates is borderline significant and opposite to the effect of the surprises on the spot 1-year rate. In other words, positive surprises to output or inflation cause farahead forward nominal interest rates to rise in tandem with short-term rates, while a surprise monetary policy tightening causes far-ahead forward nominal interest rates to fall. Gürkaynak et al. (2005) show that this is precisely the result one would expect if financial markets expected some degree of (or some chance of) pass-through from short-term inflation to the long-term inflation outlook. The $R^{2}$ for the regression, while not large in absolute terms, is more than one-third the size of that for the one-year Treasury rate in the first column, which is large for an interest rate which, in theory, ought to be close to white noise. Finally, the fact that the magnitudes of our

\footnotetext{
${ }^{18}$ See, e.g., Gürkaynak (2005).
} 
coefficients on forward rates are so similar to those for short-term interest rates suggests that our results are economically as well as statistically significant.

The final column of Table 1 repeats the analysis in the middle column, but with the tenyear-ahead forward rate computed directly from U.S. Treasury STRIPS rather than from the Federal Reserve Board's smoothed yield curve data. The advantage of using STRIPS is that they are pure zero-coupon securities whose yields provide a direct, market-based measure of forward rates that does not require any yield curve fitting or smoothing. ${ }^{19}$ (The primary disadvantage of STRIPS is that they are less liquid than Treasury notes and bonds and thus have larger transaction costs such as bid-ask spreads and price "slippage” against large orders which makes observed prices a noisier measure of the true shadow value of the securities.) As one would hope, both methods of computing forward rates produce very similar results: the signs, magnitudes, and statistical significance of the estimated coefficients are all very similar across the last two columns. This suggests that our results cannot be attributed to any artifact of yield curve fitting involved in computing forward rates from Treasury coupon securities.

\footnotetext{
${ }^{19}$ U.S. Treasury STRIPS (Separate Trading of Registered Interest and Principal Securities) are created by decoupling the individual coupon and principal payments from U.S. Treasury notes and bonds into pure zero-coupon securities. See Sack (2000) for more details and the potential usefulness of STRIPS for estimating the Treasury yield curve. We compute the one-year forward rate ending in ten years using the closest to nine-year STRIP and closest to ten-year STRIP and applying equation (1).
} 
Table 1

U.S. Forward Rate Responses to Economic News (1994-2005)

\begin{tabular}{|c|c|c|c|}
\hline & $\begin{array}{c}\text { 1-year Nominal } \\
\text { Rate }\end{array}$ & $\begin{array}{l}\text { 1-year Forward } \\
\text { Nominal Rate } \\
\text { ending in } 10 \text { yrs }\end{array}$ & $\begin{array}{l}\text { 1-year Forward } \\
\text { Nominal Rate } \\
\text { ending in } 10 \text { yrs, } \\
\text { from STRIPS }\end{array}$ \\
\hline $\begin{array}{r}\text { Capacity } \\
\text { Utilization }\end{array}$ & $\begin{array}{l}1.74 * * \\
(3.69)\end{array}$ & $\begin{array}{l}1.29 * \\
(2.00)\end{array}$ & $\begin{array}{c}0.81 \\
(1.37)\end{array}$ \\
\hline $\begin{array}{l}\text { Consumer } \\
\text { Confidence }\end{array}$ & $\begin{array}{l}1.44^{* *} \\
(3.60)\end{array}$ & $\begin{array}{l}1.15 * \\
(2.33)\end{array}$ & $\begin{array}{c}0.99 \\
(1.85)\end{array}$ \\
\hline $\begin{array}{r}\text { core Consumer } \\
\text { Price Index }\end{array}$ & $\begin{array}{l}\text { 1.91** } \\
(2.92)\end{array}$ & $\begin{array}{l}1.43 * \\
(1.96)\end{array}$ & $\begin{array}{l}1.77^{*} \\
(2.11)\end{array}$ \\
\hline $\begin{array}{l}\text { real GDP } \\
\text { (advance) }\end{array}$ & $\begin{array}{c}1.44 \\
(1.84)\end{array}$ & $\begin{array}{c}0.75 \\
(0.77)\end{array}$ & $\begin{array}{c}0.53 \\
(0.42)\end{array}$ \\
\hline $\begin{array}{r}\text { Initial } \\
\text { Jobless Claims }\end{array}$ & $\begin{array}{l}-\mathbf{0 . 9 1} * * \\
(-3.50)\end{array}$ & $\begin{array}{l}-\mathbf{0 . 6 4} 4^{* *} \\
(-2.62)\end{array}$ & $\begin{array}{c}-\mathbf{0 . 6 7 *} \\
(-2.13)\end{array}$ \\
\hline $\begin{array}{r}\text { NAPM/ISM } \\
\text { Manufacturing }\end{array}$ & $\begin{array}{l}2.41 * * \\
(4.15)\end{array}$ & $\begin{array}{l}2.55^{* *} \\
(4.36)\end{array}$ & $\begin{array}{l}2.77 * * \\
(4.56)\end{array}$ \\
\hline $\begin{array}{r}\text { New Home } \\
\text { Sales }\end{array}$ & $\begin{array}{l}\mathbf{0 . 8 2} * \\
(2.16)\end{array}$ & $\begin{array}{l}\text { 1.00* } \\
(2.26)\end{array}$ & $\begin{array}{l}1.17 * \\
(2.32)\end{array}$ \\
\hline $\begin{array}{c}\text { Nonfarm } \\
\text { Payrolls }\end{array}$ & $\begin{array}{l}\text { 4.62** } \\
(7.61)\end{array}$ & $\begin{array}{l}2.54 * * \\
(2.90)\end{array}$ & $\begin{array}{l}2.70 * * \\
(2.88)\end{array}$ \\
\hline $\begin{array}{r}\text { Retail Sales } \\
\text { (ex autos) }\end{array}$ & $\begin{array}{l}\text { 2.09** } \\
(3.44)\end{array}$ & $\begin{array}{c}1.51 \\
(1.93)\end{array}$ & $\begin{array}{c}1.14 \\
(1.41)\end{array}$ \\
\hline $\begin{array}{r}\text { Unemployment } \\
\text { Rate }\end{array}$ & $\begin{array}{c}\mathbf{- 1 . 4 1 *} \\
(-2.23)\end{array}$ & $\begin{array}{c}0.47 \\
(0.58)\end{array}$ & $\begin{array}{c}-0.09 \\
(-0.11)\end{array}$ \\
\hline $\begin{array}{r}\text { Monetary } \\
\text { Policy }\end{array}$ & $\begin{array}{l}\text { 0.27** } \\
(2.83)\end{array}$ & $\begin{array}{c}-0.18 \\
(-1.94)\end{array}$ & $\begin{array}{l}-0.26 * * \\
(-3.12)\end{array}$ \\
\hline \# Observations & 1366 & 1366 & 1366 \\
\hline$R^{2}$ & .16 & .06 & .05 \\
\hline Joint test p-value & $.0000 * *$ & $.0000 * *$ & $.0000 * *$ \\
\hline
\end{tabular}

Notes: Sample: Feb 1994-Dec 2005 at daily frequency on the dates of macroeconomic and monetary policy announcements. Heteroskedasticity-consistent $\mathrm{t}$-statistics reported in parentheses. ** indicates statistical significance at the $1 \%$ level and * at the 5\% level. Regressions include a constant, a Y2K dummy that takes on the value 1 on the first business day of 2000, and a year-end dummy that takes on the value 1 on the first business day of any year (coefficients not reported). Macroeconomic data release surprises are normalized by their standard deviations, so that coefficients represent a basis point per standard deviation response. Monetary policy surprises are in basis points, so that those coefficients represent a basis point per basis point response. Joint test p-value is for the hypothesis that all 11 coefficients (other than the constant and dummy variables) are zero. See text for details. 


\subsection{The Sensitivity of U.S. Inflation Compensation to Economic News}

In Table 2, we turn to the natural question of whether and to what extent the strong responses in far-ahead forward nominal interest rates in Table 1 are due to changes in real interest rates as opposed to changes in inflation compensation - the difference between nominal and real interest rates. In the first two columns of Table 2, we repeat the regressions of the spot one-year rate and the 10-year-ahead one-year nominal rate on our macroeconomic surprises over the shorter sample for which we have inflation-indexed Treasury (TIPS) data, $1998-2005 .^{20}$ Our coefficient estimates over this sample are very similar to those in Table 1, although the statistical significance is reduced somewhat in both regressions, perhaps due to the smaller sample size; it remains true, however, that the joint hypotheses that all coefficients are zero in those regressions continue to be overwhelmingly rejected. $^{21}$

In the third and fourth columns of Table 2, we break the response of forward nominal interest rates out into real interest rate and inflation compensation components. The evidence in the third column does suggest that part of the sensitivity of forward nominal rates to economic news may be due to movements in real interest rates, at least for the NAPM/ISM manufacturing survey and nonfarm payrolls releases. We do not take a stand in this paper on why far-ahead real rates might move in response to economic news, although one possible explanation is that markets view those releases as informative about the long-run rate of productivity growth, and hence the equilibrium real interest rate, in the economy. The key observation to take away from Table 2 is that in almost every case, the sensitivity of far-ahead forward nominal interest rates in the second column is attributable to changes in the inflation compensation component, at least partly if not primarily. Five out of the eleven coefficients in the last column are statistically significant and the joint hypothesis that all coefficients in that column are zero is rejected with a $p$-value far below 1 percent.

\footnotetext{
${ }^{20}$ Although TIPS were first issued in 1997, recall that we can only compute a forward rate beginning in January 1998.

${ }^{21}$ A possible explanation for the smaller number of significant coefficients over the later sample-other than simply a smaller sample size - is that long-term interest rates in the U.S. have become better anchored over time. We do not explore this possibility here but leave it as an interesting question for future research.
} 
Thus, there is substantial evidence that far-ahead forward nominal interest rates and inflation compensation in the U.S. are much more sensitive to economic news than one would expect based on the benchmark model results presented earlier. Before turning to interpretations, we first investigate to what extent these observations also hold in the U.K. and Sweden. 
Table 2

U.S. Forward Rate Responses to Economic News (1998-2005)

\begin{tabular}{|c|c|c|c|c|}
\hline & $\begin{array}{c}\text { 1-year } \\
\text { Nominal Rate }\end{array}$ & $\begin{array}{l}\text { 1-year Forward } \\
\text { Nominal Rate } \\
\text { ending in } 10 \text { yrs }\end{array}$ & $\begin{array}{l}\text { 1-year Forward } \\
\text { Real Rate } \\
\text { ending in } 10 \text { yrs }\end{array}$ & $\begin{array}{c}\text { 1-year Forward } \\
\text { Inflation } \\
\text { Compensation } \\
\text { ending in } 10 \text { yrs } \\
\end{array}$ \\
\hline $\begin{array}{r}\text { Capacity } \\
\text { Utilization }\end{array}$ & $\begin{array}{l}1.57 * * \\
(2.76)\end{array}$ & $\begin{array}{c}0.98 \\
(1.68)\end{array}$ & $\begin{array}{c}0.46 \\
(1.74)\end{array}$ & $\begin{array}{c}0.52 \\
(0.94)\end{array}$ \\
\hline $\begin{array}{l}\text { Consumer } \\
\text { Confidence }\end{array}$ & $\begin{array}{l}1.46 * * \\
(2.89)\end{array}$ & $\begin{array}{c}0.62 \\
(0.99)\end{array}$ & $\begin{array}{c}0.19 \\
(0.47)\end{array}$ & $\begin{array}{c}0.43 \\
(0.94)\end{array}$ \\
\hline $\begin{array}{r}\text { core Consumer } \\
\text { Price Index }\end{array}$ & $\begin{array}{c}0.98 \\
(1.51)\end{array}$ & $\begin{array}{c}1.18 \\
(1.74)\end{array}$ & $\begin{array}{c}-0.24 \\
(-0.57)\end{array}$ & $\begin{array}{l}1.42 * \\
(2.30)\end{array}$ \\
\hline $\begin{array}{l}\text { real GDP } \\
\text { (advance) }\end{array}$ & $\begin{array}{c}2.17^{*} \\
(2.51)\end{array}$ & $\begin{array}{l}2.07 * \\
(2.22)\end{array}$ & $\begin{array}{c}0.30 \\
(0.52)\end{array}$ & $\begin{array}{l}1.77^{*} \\
(2.06)\end{array}$ \\
\hline $\begin{array}{r}\text { Initial } \\
\text { Jobless Claims }\end{array}$ & $\begin{array}{l}-1.13^{* *} \\
(-3.79)\end{array}$ & $\begin{array}{c}-0.73 * \\
(-2.53)\end{array}$ & $\begin{array}{c}-0.21 \\
(-1.32)\end{array}$ & $\begin{array}{l}-\mathbf{0 . 5 1} \\
(-2.10)\end{array}$ \\
\hline $\begin{array}{r}\text { NAPM/ISM } \\
\text { Manufacturing }\end{array}$ & $\begin{array}{l}2.28 * * \\
(2.65)\end{array}$ & $\begin{array}{l}2.98 * * \\
(4.27)\end{array}$ & $\begin{array}{l}1.50 * * \\
(3.52)\end{array}$ & $\begin{array}{c}\mathbf{1 . 4 8}^{*} \\
(2.55)\end{array}$ \\
\hline $\begin{array}{r}\text { New Home } \\
\text { Sales }\end{array}$ & $\begin{array}{c}0.53 \\
(1.36)\end{array}$ & $\begin{array}{l}\text { 1.15* } \\
(2.38)\end{array}$ & $\begin{array}{c}-0.27 \\
(-0.98)\end{array}$ & $\begin{array}{l}1.42 * * \\
(3.47)\end{array}$ \\
\hline Nonfarm Payrolls & $\begin{array}{l}4.44 * * \\
(7.03)\end{array}$ & $\begin{array}{l}1.84^{*} \\
(2.26)\end{array}$ & $\begin{array}{l}1.32 * * \\
(3.46)\end{array}$ & $\begin{array}{c}0.52 \\
(0.83)\end{array}$ \\
\hline $\begin{array}{r}\text { Retail Sales } \\
\text { (ex autos) }\end{array}$ & $\begin{array}{l}\text { 1.69** } \\
(2.68)\end{array}$ & $\begin{array}{c}1.44 \\
(1.70)\end{array}$ & $\begin{array}{c}0.56 \\
(1.48)\end{array}$ & $\begin{array}{c}0.88 \\
(1.45)\end{array}$ \\
\hline $\begin{array}{r}\text { Unemployment } \\
\text { Rate }\end{array}$ & $\begin{array}{l}-0.97 \\
(-1.47)\end{array}$ & $\begin{array}{c}0.78 \\
(0.79)\end{array}$ & $\begin{array}{c}0.89 \\
(1.36)\end{array}$ & $\begin{array}{c}-0.11 \\
(-0.15)\end{array}$ \\
\hline $\begin{array}{r}\text { Monetary } \\
\text { Policy }\end{array}$ & $\begin{array}{c}\text { 0.23* } \\
(2.02)\end{array}$ & $\begin{array}{c}-0.12 \\
(-1.43)\end{array}$ & $\begin{array}{c}0.00 \\
(0.03)\end{array}$ & $\begin{array}{c}-0.12 \\
(-1.43)\end{array}$ \\
\hline \# Observations & 971 & 971 & 971 & 971 \\
\hline$R^{2}$ & .14 & .06 & .04 & .04 \\
\hline Joint test p-value & $.0000 * *$ & $.0000 * *$ & $.0005 * *$ & $.0002 * *$ \\
\hline
\end{tabular}

Notes: Sample: Jan 1998-Dec 2005 at daily frequency on the dates of macroeconomic and monetary policy announcements. Heteroskedasticity-consistent t-statistics reported in parentheses. ${ }^{* *}$ indicates statistical significance at the $1 \%$ level and * at the $5 \%$ level. Regressions also include a constant, a Y2K dummy that takes on the value 1 on the first business day of 2000, and a year-end dummy that takes on the value 1 on the first business day of any year (coefficients not reported). Macroeconomic data release surprises are normalized by their standard deviations, so that coefficients represent a basis point per standard deviation response. Monetary policy surprises are in basis points, so that those coefficients represent a basis point per basis point response. Inflation compensation is the difference between nominal and real rates. Joint test p-value is for the hypothesis that all 11 coefficients (other than the constant and dummy variables) are zero. See text for details. 


\subsection{The Sensitivity of U.K. Forward Rates and Inflation Compensation to Economic News}

In Tables 3 and 4, we repeat the above analysis for the United Kingdom. The U.K. officially adopted an inflation target of 2.5 percent in October 1992, but there is a potential structural break in the British data due to the Bank of England (the central bank) gaining independence from Parliament between May 1997 and June 1998. ${ }^{22}$ The lack of independence of the central bank in the pre-1997 period arguably led to a diminished level of credibility with respect to the inflation target, an idea that is supported by levels of long-term inflation expectations from surveys and bond yield data in the U.K. that were substantially higher than the official inflation target of 2.5 percent over this period. ${ }^{23}$

Table 3 reports results for the U.K. for the first of these sample periods, February 1993 to April 1997. ${ }^{24}$ The format of the table is the same as Table 2. The results in Table 3 are also quite similar to those for the United States: First, the response of short-term interest rates to economic news is very similar in sign, magnitude, and statistical significance to what we estimated for the U.S. Second, far-ahead forward nominal interest rates appear to be very sensitive to economic news in the U.K., with four of the seven coefficients displaying a high degree of statistical significance and a $p$-value that overwhelmingly rejects the joint hypothesis that the announcements have no effect. As in the U.S., these coefficients are very similar in magnitude to those for shortterm rates, implying that the sensitivity is economically as well as statistically significant. Indeed, far-ahead forward rates in the pre-1997 U.K. are even more sensitive to economic news than are those in the U.S. as measured by regression $R^{2}$, both in absolute terms and relative to short-term interest rates. Third, the sensitivity of forward nominal interest rates in the U.K. is due primarily to

\footnotetext{
${ }^{22}$ On May 6, 1997, Chancellor of the Exchequer Gordon Brown announced that the Bank of England would be granted independence, and The Bank of England Act 1998 was passed into law by Parliament on April 23, 1998, with an effective date of June 1, 1998. The May 6, 1997, announcement came as a surprise to financial markets, particularly the scope of the announcement: according to the BBC, the "surprise announcement... is being described as the most radical shake-up in the Bank’s 300-year history” (British Broadcasting Corporation, 1997).

${ }^{23}$ See Levin and Piger (2002) for survey data on long-term inflation expectations in the U.K. Figure 3, below, provides a graph of the level of forward inflation compensation for the U.K. from 1992 to 2005.

${ }^{24}$ The MMS data for U.K. macroeconomic data releases begin in February 1993.
} 
movements in the inflation compensation component rather than the real rate component. ${ }^{25}$ Fourth, far-ahead forward nominal rates and inflation compensation in the U.K. over this period both respond inversely to monetary policy announcements, to an extent that is even greater than was the case for the U.S.- -in other words, surprise monetary policy tightenings in the U.K. had an even greater negative impact on far-ahead forward nominal rates and inflation compensation than one might have expected based on our estimates from the U.S. Finally, all of the significant coefficients in Table 3, including those on monetary policy announcements, are consistent with the view that financial markets expected there to be some degree of pass-through (or some chance of pass-through) of inflation in the near term to inflation at much longer horizons.

In Table 4, we investigate whether the sensitivity of long-term interest rates in the U.K. to economic news continued after the Bank of England gained independence. The results in Table 4 are strikingly different from those for the pre-independence period: Although short-term interest rates in the first column continue to respond to economic news in very much the same way as in the earlier period, far-ahead forward nominal interest rates and inflation compensation now show essentially no sensitivity to economic news. In fact, the one coefficient for these forward rates that we do find to be statistically significant (on retail sales) enters with a negative sign, which is inconsistent with the idea of pass-through of short-term inflation to the long-term inflation outlook and thus does not match our findings for the earlier period at all. Finally, in both the second and fourth columns, the data do not reject the joint hypothesis that all of the coefficients on the economic data releases are zero at standard significance levels and the regression $R^{2}$ are small, both in absolute terms and relative to the explainable variation in short-term rates.

\footnotetext{
${ }^{25}$ Far-ahead forward real rates in the U.K. also appear to respond to economic news, but to a much lesser extent than inflation compensation; as in the U.S., we do not take a stand on why long-term real rates in the U.K might respond to economic news, but note that there could be several explanations, such as changes in the expected long-run rate of productivity growth.
} 
Table 3

\section{U.K. Forward Rate Responses to Economic News, pre-Bank of England Independence (1993-April 1997)}

\begin{tabular}{|c|c|c|c|c|}
\hline & $\begin{array}{c}\text { 1-year } \\
\text { Nominal Rate }\end{array}$ & $\begin{array}{l}\text { 1-year Forward } \\
\text { Nominal Rate } \\
\text { ending in } 10 \text { yrs }\end{array}$ & $\begin{array}{l}\text { 1-year Forward } \\
\text { Real Rate } \\
\text { ending in } 10 \text { yrs }\end{array}$ & $\begin{array}{c}\text { 1-year Forward } \\
\text { Inflation } \\
\text { Compensation } \\
\text { ending in } 10 \text { yrs }\end{array}$ \\
\hline $\begin{array}{c}\text { Average } \\
\text { Earnings }\end{array}$ & $\begin{array}{l}3.23^{* *} \\
(3.33)\end{array}$ & $\begin{array}{c}0.69 \\
(0.82)\end{array}$ & $\begin{array}{c}0.55 \\
(1.72)\end{array}$ & $\begin{array}{c}0.15 \\
(0.20)\end{array}$ \\
\hline $\begin{array}{r}\text { real GDP } \\
\text { (preliminary) }\end{array}$ & $\begin{array}{l}1.75 \\
(1.68)\end{array}$ & $\begin{array}{l}2.36 * \\
(2.14)\end{array}$ & $\begin{array}{c}0.55 \\
(1.71)\end{array}$ & $\begin{array}{l}1.80 * \\
(2.02)\end{array}$ \\
\hline $\begin{array}{r}\text { Manufacturing } \\
\text { Production }\end{array}$ & $\begin{array}{c}0.76 \\
(0.88)\end{array}$ & $\begin{array}{c}-0.27 \\
(-0.21)\end{array}$ & $\begin{array}{c}-0.60 \\
(-1.76)\end{array}$ & $\begin{array}{c}0.33 \\
(0.29)\end{array}$ \\
\hline $\begin{array}{r}\text { Producer } \\
\text { Price Index }\end{array}$ & $\begin{array}{l}2.13^{* *} \\
(3.12)\end{array}$ & $\begin{array}{l}\text { 2.98** } \\
(2.95)\end{array}$ & $\begin{array}{l}\text { 0.76* } \\
(2.30)\end{array}$ & $\begin{array}{l}2.22 * \\
(2.61)\end{array}$ \\
\hline $\begin{array}{l}\text { core Retail } \\
\text { Price Index }\end{array}$ & $\begin{array}{l}2.39 * * \\
(3.19)\end{array}$ & $\begin{array}{l}3.21 * * \\
(3.07)\end{array}$ & $\begin{array}{c}0.62 \\
(1.88)\end{array}$ & $\begin{array}{l}2.60 * * \\
(3.08)\end{array}$ \\
\hline Retail Sales & $\begin{array}{l}2.17 * * \\
(2.98)\end{array}$ & $\begin{array}{c}0.32 \\
(0.30)\end{array}$ & $\begin{array}{c}0.51 \\
(1.17)\end{array}$ & $\begin{array}{l}-0.19 \\
(-0.24)\end{array}$ \\
\hline $\begin{array}{r}\text { Monetary } \\
\text { Policy }\end{array}$ & $\begin{array}{l}\mathbf{0 . 6 7 * *} \\
(5.73)\end{array}$ & $\begin{array}{l}-\mathbf{0 . 5 4} 4^{* *} \\
(-3.91)\end{array}$ & $\begin{array}{c}0.06 \\
(1.27)\end{array}$ & $\begin{array}{l}\mathbf{- 0 . 6 0 * *} \\
(-5.99)\end{array}$ \\
\hline \# Observations & 237 & 237 & 237 & 237 \\
\hline$R^{2}$ & .35 & .18 & .07 & .21 \\
\hline Joint test p-value & $.0000 * *$ & $.0000 * *$ & $.003 * *$ & $.0000 * *$ \\
\hline
\end{tabular}

Notes: Sample is Feb 1993-Apr 1997 at daily frequency on the dates of macroeconomic and monetary policy announcements. Heteroskedasticity-consistent t-statistics reported in parentheses. ${ }^{* *}$ indicates statistical significance at the $1 \%$ level and ${ }^{*}$ at the $5 \%$ level. Regressions also include a constant and a year-end dummy that takes on the value 1 on the first business day of any year (coefficients not reported). Macroeconomic data release surprises are normalized by their full-sample standard deviations, so that coefficients represent a basis point per standard deviation response. Monetary policy surprises are in basis points, so that those coefficients represent a basis point per basis point response. Inflation compensation is the difference between nominal and real rates. Joint test p-value is for the hypothesis that all 7 coefficients (other than the constant and dummy variables) are zero. See text for details. 


\section{Table 4}

\section{U.K. Forward Rate Responses to Economic News, post-Bank of England Independence (July 1998-2005)}

\begin{tabular}{|c|c|c|c|c|}
\hline & $\begin{array}{c}\text { 1-year } \\
\text { Nominal Rate }\end{array}$ & $\begin{array}{l}\text { 1-year Forward } \\
\text { Nominal Rate } \\
\text { ending in } 10 \text { yrs }\end{array}$ & $\begin{array}{l}\text { 1-year Forward } \\
\text { Real Rate } \\
\text { ending in } 10 \text { yrs }\end{array}$ & $\begin{array}{l}\text { 1-year Forward } \\
\text { Inflation } \\
\text { Compensation } \\
\text { ending in } 10 \text { yrs }\end{array}$ \\
\hline $\begin{array}{l}\text { Average } \\
\text { Earnings }\end{array}$ & $\begin{array}{l}\text { 1.81** } \\
(4.12)\end{array}$ & $\begin{array}{c}-0.38 \\
(-1.15)\end{array}$ & $\begin{array}{c}-0.12 \\
(-0.53)\end{array}$ & $\begin{array}{c}-0.26 \\
(-0.94)\end{array}$ \\
\hline $\begin{array}{r}\text { real GDP } \\
\text { (preliminary) }\end{array}$ & $\begin{array}{l}2.04^{* *} \\
(4.02)\end{array}$ & $\begin{array}{l}-0.53 \\
(-0.47)\end{array}$ & $\begin{array}{c}-0.03 \\
(-0.09)\end{array}$ & $\begin{array}{c}-0.49 \\
(-0.54)\end{array}$ \\
\hline $\begin{array}{l}\text { Manufacturing } \\
\text { Production }\end{array}$ & $\begin{array}{l}1.26 * * \\
(3.09)\end{array}$ & $\begin{array}{c}0.59 \\
(1.08)\end{array}$ & $\begin{array}{l}\mathbf{0 . 6 3} * * \\
(2.69)\end{array}$ & $\begin{array}{c}-0.04 \\
(-0.09)\end{array}$ \\
\hline $\begin{array}{r}\text { Producer } \\
\text { Price Index }\end{array}$ & $\begin{array}{c}0.21 \\
(0.55)\end{array}$ & $\begin{array}{c}0.22 \\
(0.58)\end{array}$ & $\begin{array}{c}0.44 \\
(1.88)\end{array}$ & $\begin{array}{c}-0.22 \\
(-0.63)\end{array}$ \\
\hline $\begin{array}{l}\text { core Retail } \\
\text { Price Index }\end{array}$ & $\begin{array}{l}2.60 * * \\
(4.83)\end{array}$ & $\begin{array}{c}-0.89 \\
(-1.84)\end{array}$ & $\begin{array}{c}-0.13 \\
(-0.53)\end{array}$ & $\begin{array}{c}-0.76 \\
(-1.95)\end{array}$ \\
\hline Retail Sales & $\begin{array}{l}\text { 1.58** } \\
(3.92)\end{array}$ & $\begin{array}{c}-\mathbf{1 . 0 8 *} \\
(-2.05)\end{array}$ & $\begin{array}{c}0.09 \\
(0.34)\end{array}$ & $\begin{array}{l}\mathbf{- 1 . 1 8 * *} \\
(-2.75)\end{array}$ \\
\hline $\begin{array}{r}\text { Monetary } \\
\text { Policy }\end{array}$ & $\begin{array}{l}\text { 0.72** } \\
(5.96)\end{array}$ & $\begin{array}{c}-0.12 \\
(-0.92)\end{array}$ & $\begin{array}{c}0.01 \\
(0.20)\end{array}$ & $\begin{array}{c}-0.13 \\
(-1.01)\end{array}$ \\
\hline \# Observations & 480 & 480 & 480 & 480 \\
\hline$R^{2}$ & .24 & .02 & .02 & .03 \\
\hline Joint test p-value & $.0000 * *$ & .119 & .123 & .051 \\
\hline \multicolumn{5}{|c|}{ 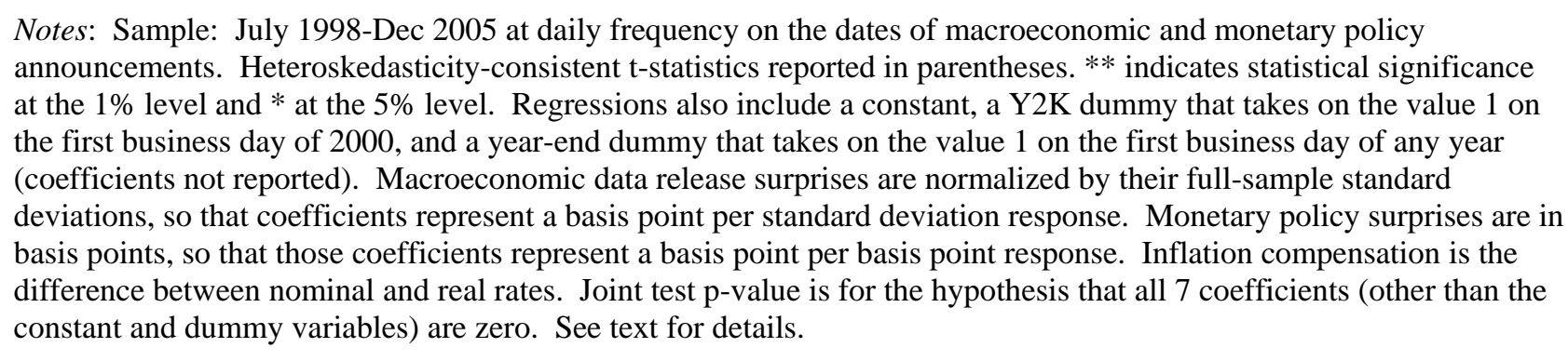 } \\
\hline
\end{tabular}




\subsection{The Sensitivity of Swedish Forward Rates and Inflation Compensation to Economic News}

In Table 5, we repeat the same analysis for Sweden. Like the U.K., Sweden has been an official inflation targeter throughout much of the 1990s: After abandoning its currency peg in late 1992, the Riksbank (the Swedish central bank) announced in January 1993 that it would adopt an inflation targeting framework with an official target of 2 percent that would become effective beginning in January 1995 (thus, there is some ambiguity about exactly what date should be regarded as the beginning of the inflation targeting regime in Sweden). Our inflation-indexed bond yield data for Sweden begin in May 1996, so we begin our analysis of Sweden with that date, which has the added advantage of giving the Riksbank a few years to gain operational experience within the new floating exchange rate regime and to establish some degree of credibility with respect to the inflation target (see, e.g., Berg and Grottheim, 1997).

As can be seen in Table 5, the results for Sweden are strikingly different from those for the U.S. and the pre-independence U.K., and are very similar to those for the U.K. after the Bank of England gained independence. While the regression $R^{2}$ for the short rate is not as high for Sweden as it is for the U.S. or U.K. (perhaps because our data on major Swedish economic announcements is less comprehensive than our data for the U.S. and U.K.), short-term interest rates in Sweden nonetheless respond with a high degree of statistical significance to three major macroeconomic and monetary policy announcements, with signs and magnitudes that are consistent with our previous estimates for the U.S. and U.K. Moreover, the data overwhelmingly reject the hypothesis that the one-year rate in Sweden is unrelated to these announcements. Yet far-ahead forward nominal interest rates and inflation compensation in Sweden show no statistically significant relationship to any of these releases, and the joint hypothesis that the coefficients on all of these releases are zero is not rejected. 
Table 5

Swedish Forward Rate Responses to Economic News (1996-2005)

\begin{tabular}{|c|c|c|c|c|}
\hline & $\begin{array}{c}\text { 1-year } \\
\text { Nominal Rate }\end{array}$ & $\begin{array}{l}\text { 1-year Forward } \\
\text { Nominal Rate } \\
\text { ending in } 10 \text { yrs }\end{array}$ & $\begin{array}{l}\text { 1-year Forward } \\
\text { Real Rate } \\
\text { ending in } 10 \text { yrs }\end{array}$ & $\begin{array}{c}\text { 1-year Forward } \\
\text { Inflation } \\
\text { Compensation } \\
\text { ending in } 10 \text { yrs }\end{array}$ \\
\hline $\begin{array}{l}\text { Consumer } \\
\text { Price Index }\end{array}$ & $\begin{array}{l}\text { 1.94* } \\
(2.55)\end{array}$ & $\begin{array}{l}1.01 \\
(1.25)\end{array}$ & $\begin{array}{l}0.16 \\
(0.64)\end{array}$ & $\begin{array}{c}0.85 \\
(1.13)\end{array}$ \\
\hline $\begin{array}{r}\text { core Consumer } \\
\text { Price Index }\end{array}$ & $\begin{array}{l}2.72 * * \\
(4.26)\end{array}$ & $\begin{array}{c}-0.68 \\
(-0.71)\end{array}$ & $\begin{array}{c}-0.36 \\
(-0.96)\end{array}$ & $\begin{array}{c}-0.33 \\
(-0.37)\end{array}$ \\
\hline $\begin{array}{r}\text { real GDP } \\
\text { (preliminary) }\end{array}$ & $\begin{array}{c}0.79 \\
(1.17)\end{array}$ & $\begin{array}{c}0.72 \\
(1.12)\end{array}$ & $\begin{array}{c}0.43 \\
(0.94)\end{array}$ & $\begin{array}{c}0.29 \\
(0.45)\end{array}$ \\
\hline $\begin{array}{l}\text { Industrial } \\
\text { Production }\end{array}$ & $\begin{array}{c}-0.14 \\
(-0.24)\end{array}$ & $\begin{array}{c}-0.71 \\
(-1.31)\end{array}$ & $\begin{array}{c}-0.04 \\
(-0.14)\end{array}$ & $\begin{array}{c}-0.67 \\
(-1.55)\end{array}$ \\
\hline $\begin{array}{r}\text { Producer } \\
\text { Price Index }\end{array}$ & $\begin{array}{c}0.63 \\
(0.83)\end{array}$ & $\begin{array}{c}-0.47 \\
(-1.41)\end{array}$ & $\begin{array}{c}-0.23 \\
(-1.01)\end{array}$ & $\begin{array}{c}-0.24 \\
(-0.76)\end{array}$ \\
\hline Retail Sales & $\begin{array}{c}-0.49 \\
(-0.72)\end{array}$ & $\begin{array}{c}0.26 \\
(0.49)\end{array}$ & $\begin{array}{c}-0.39 \\
(-1.93)\end{array}$ & $\begin{array}{c}0.65 \\
(1.21)\end{array}$ \\
\hline Unemployment & $\begin{array}{c}-0.26 \\
(-0.67)\end{array}$ & $\begin{array}{c}-0.42 \\
(-0.93)\end{array}$ & $\begin{array}{c}-0.37 \\
(-1.57)\end{array}$ & $\begin{array}{c}-0.04 \\
(-0.11)\end{array}$ \\
\hline $\begin{array}{r}\text { Monetary } \\
\text { Policy }\end{array}$ & $\begin{array}{l}\text { 0.72** } \\
(3.62)\end{array}$ & $\begin{array}{c}0.25 \\
(1.56)\end{array}$ & $\begin{array}{c}0.03 \\
(0.63)\end{array}$ & $\begin{array}{c}0.23 \\
(1.48)\end{array}$ \\
\hline \# Observations & 514 & 514 & 514 & 514 \\
\hline$R^{2}$ & .07 & .02 & .02 & .01 \\
\hline oint test p-value & $.0000 * *$ & .337 & .341 & .420 \\
\hline
\end{tabular}

Notes: Sample: May 1996-Dec 2005 at daily frequency on the dates of macroeconomic and monetary policy announcements. Heteroskedasticity-consistent t-statistics reported in parentheses. ** indicates statistical significance at the $1 \%$ level and * at the 5\% level. Regressions also include a constant, a Y2K dummy that takes on the value 1 on the first business day of 2000, and a year-end dummy that takes on the value 1 on the first business day of any year (coefficients not reported). Macroeconomic data release surprises are normalized by their standard deviations, so that coefficients represent a basis point per standard deviation response. Monetary policy surprises are in basis points, so that those coefficients represent a basis point per basis point response. Inflation compensation is the difference between nominal and real rates. Joint test p-value is for hypothesis that all 8 coefficients (other than the constant and dummy variables) are zero. See text for details. 


\subsection{Summary and Interpretation}

Figure 2 provides a graphical summary of the sensitivity of far-ahead forward inflation compensation in the U.S., U.K., and Sweden to economic news. Each graph in the figure presents a scatter plot of the surprise component of economic announcements along the horizontal axis (GDP in panel a, inflation in panel b, and monetary policy in panel c) against the corresponding daily change in far-ahead forward inflation compensation along the vertical axis. Regression lines are also included in each plot for reference. The difference between the U.S. and pre-1997 U.K. on the one hand versus Sweden and the post-1998 U.K. on the other is often striking, with the scatter plots generally exhibiting a clear positive relationship for GDP and inflation in the U.S. and preindependence U.K. and no relationship in Sweden or the post-independence U.K.

A natural interpretation of these results is that financial market perceptions of the distribution of long-run inflation outcomes in the U.S. and pre-1997 U.K. are (or were) not wellanchored and responded significantly to economic news. Indeed, all of our empirical findings for these two countries are consistent with markets at the time expecting some degree of, or at least some chance of, pass-through from short-term inflation to the long-term inflation outlook. ${ }^{26}$ In both cases, this is arguably because the central bank's long-run inflation objective was not well known and credible: In the U.S., the Federal Reserve’s long-run inflation objective is vague and imprecise, described only as a desire for “price stability.” In the pre-independence U.K., although there was an official inflation target that was well known, that objective was arguably not credible due to the close ties between the Bank of England and Parliament. By contrast, in Sweden and in the U.K. since 1998, far-ahead forward nominal rates and inflation compensation have been relatively stable around economic announcements, consistent with the view that a well-known and credible inflation target helps to anchor private sector views regarding the distribution of long-run inflation outcomes.

\footnotetext{
${ }^{26}$ In this paper, we do not modify the models of section 2 to explicitly include a time-varying inflation target of the central bank. Gurkaynak, et al. (2005) do modify a simple hybrid New Keynesian model to include a time-varying inflation target and show that impulse responses from this model do indeed match the empirical evidence from the high-frequency term-structure responses to news.
} 
Although there exist other potential interpretations of our empirical findings, which we turn to in the next section, these alternatives have a difficult time explaining all of our findings within a single, simple framework. Our interpretation above also matches anecdotal evidence from the financial press at the time: for example, the story behind the point in the bottom-right corner of the pre-1997 U.K. plot in Figure 2c is itself interesting and supportive. On September 12, 1994, as reported in The Economist shortly after the move, Chancellor of the Exchequer Kenneth Clarke "became the first chancellor in living memory to take the unpopular step of raising interest rates not in response to soaring prices or a sterling crisis, but as a prudent move against future inflation... Financial markets have hitherto been sceptical of the government's ability to meet its inflation target... The chancellor's display of mettle strengthened his government's credibility and, as a result, caused long-term interest rates to fall."

(The Economist, 1994)

Several aspects of the quote support the view that long-term inflation expectations in the U.K. at the time were not well anchored: First, the observation in question appears to be genuine rather than an anomaly in the data, which supports the strong statistical significance of the coefficient on monetary policy announcements in that regression. Second, despite the existence of an official inflation target prior to Bank of England independence, the quote reports that financial markets viewed the credibility and commitment of the Bank to the target with skepticism, as we have suggested. Finally, the article directly attributes the change in British long-term interest rates that day to the economic news that was released on the day and, in particular, to changes in financial markets' perceptions of the long-term inflation outlook. ${ }^{27}$ This is exactly the channel that we are proposing to explain all of our results more broadly.

\footnotetext{
${ }^{27}$ The Economist's analysis of the Bank of England's move, rather than being idiosyncratic, was echoed throughout the British press at the time. For example, The Financial Times reported the day after the move that: "Mr. Kenneth Clarke, the chancellor, boosted his credibility," that "the Bank of England's reputation was also enhanced,” and that "the clear message is that the Bank of England has much more independence in setting monetary policy than at any time in its history" (The Financial Times, 1994).
} 
Figure 2: Response of Forward Inflation Compensation to Economic News

(a) GDP Surprises
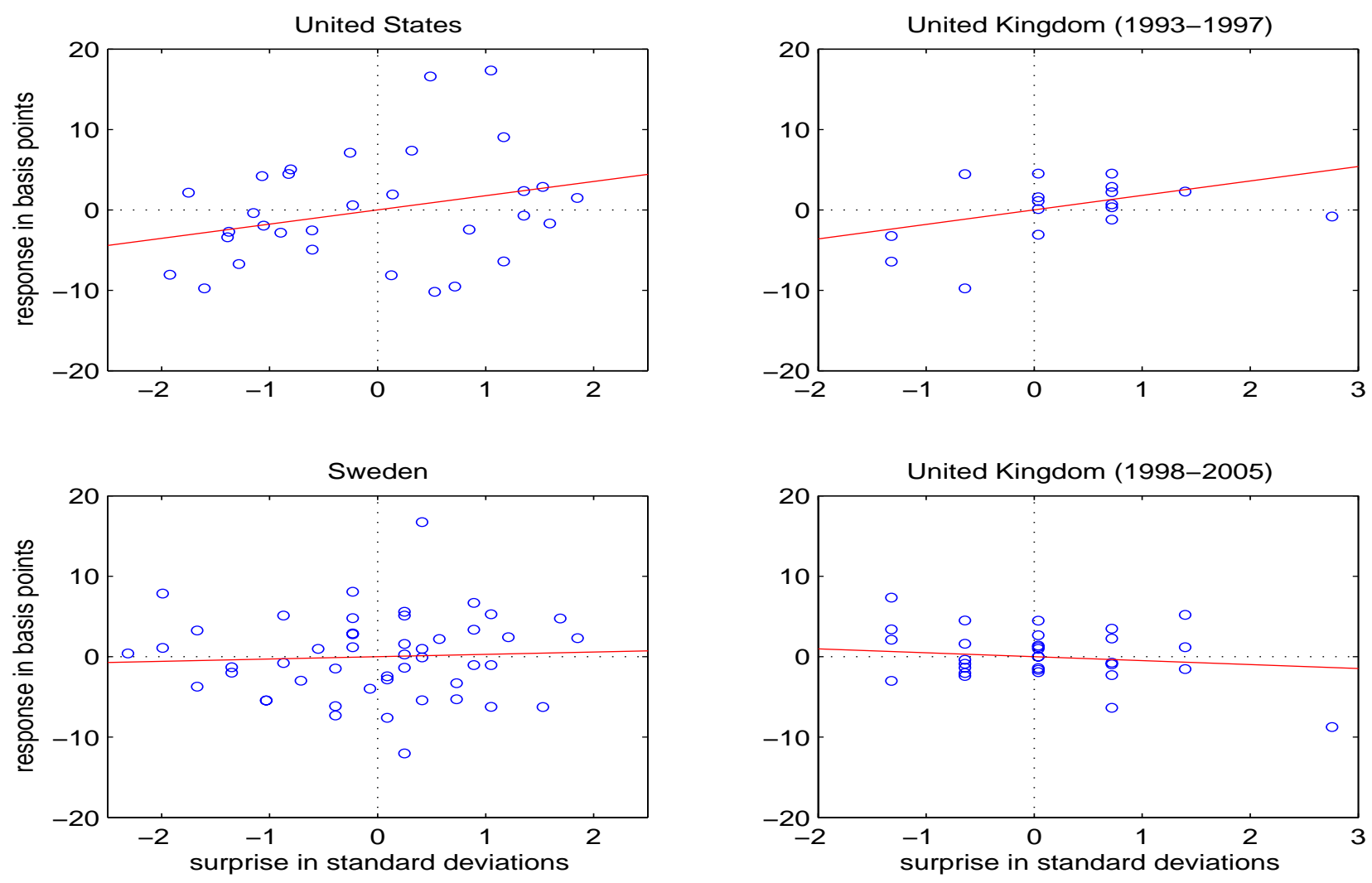

(b) Inflation Surprises
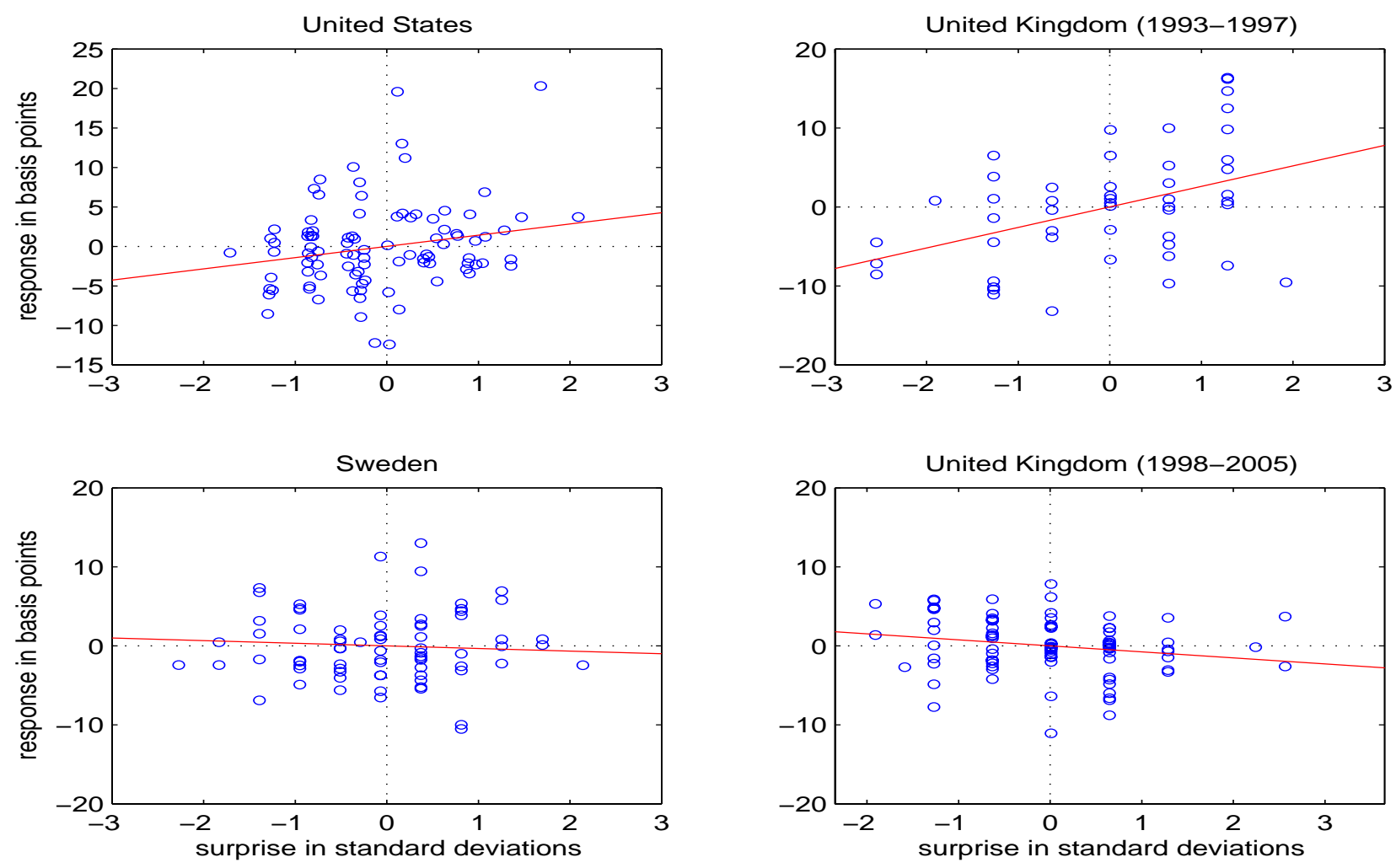
Figure 2 (continued)

\section{Response of Forward Inflation Compensation to Economic News}

(c) Monetary Policy Surprises
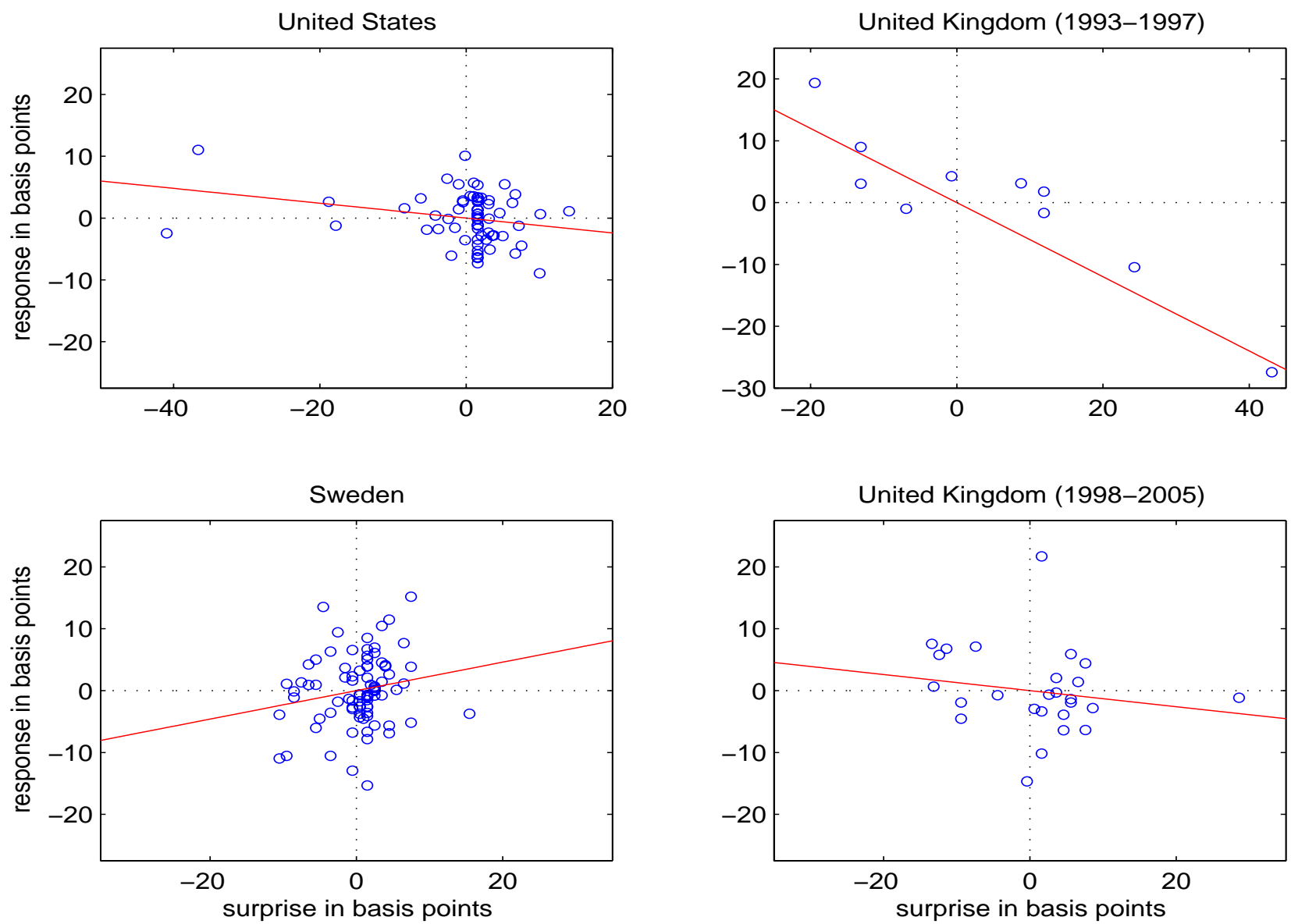


\section{Discussion and Sensitivity Analysis}

In this section we present additional analysis of the sensitivity of forward interest rates and inflation compensation in the U.S., U.K. and Sweden and discuss possible alternative explanations for our findings, particularly the possibility that risk premia vary over time and in response to news.

\subsection{Time Series of Forward Nominal Rates and Inflation Compensation}

While our regression results suggest that a credible inflation target has helped the U.K. and Sweden to anchor inflation expectations, it should be noted that far-ahead forward interest rates and inflation compensation in these two countries nonetheless do vary over time. Figure 3 plots the daily time series of far-ahead forward nominal rates and inflation compensation for each of the U.S., U.K., and Sweden. There are at least five key observations to take away from these figures, which we discuss in detail.

First, it is not the case that the far-ahead nominal rates or inflation compensation in any of the three countries is completely stable. There is clear variation both at high and low frequencies, the source of which remains an open question—possible explanations include time-varying term or liquidity premia (which we discuss in greater detail below); ${ }^{28}$ variations in financial market perceptions of the credibility and commitment of the central bank to its long-run inflation objective; changes in current and expected future taxes; differences between the consumption deflator of the marginal investor and the price index that is being targeted by the central bank; market perceptions that the central bank's targeted price index might change in the future; and market perceptions that the central bank's numerical target for a given price index might change in the future.

\footnotetext{
${ }^{28}$ There is some evidence of an upward trend in Swedish and U.S. inflation compensation from 1998 to 2005, which is often attributed to the improving liquidity of inflation-indexed securities in these countries. For example, the lack of liquidity and high transactions costs in the secondary U.S. TIPS market in its early years is generally thought to have caused TIPS yields to be higher than they otherwise would have been (Sack and Elsasser, 2004), which in turn causes measured inflation compensation to be lower over this period. Note that liquidity in the secondary TIPS market has increased steadily over time and is now regarded as being quite good, suggesting that there is relatively little lowliquidity yield premium remaining in these securities at present.
} 
Second, despite the fact that variation in far-ahead forward nominal rates and inflation compensation remains in the U.K. and Sweden, the improvements that these two countries have realized in these rates are nothing short of spectacular. In the first half of the 1990s, far-ahead forward rates in the U.K. and Sweden were clearly and consistently higher and more volatile than in the U.S. (panel a). From the late 1990s onward, that situation had completely reversed: farahead forward rates in the U.K. and Sweden have been clearly and consistently lower than in the U.S. and, in the case of the U.K., less volatile. This reversal is all the more striking in light of the facts that, first, U.S. Treasury markets are by far the largest and most liquid in the world and, second, the U.S. tends to excel in comparison to other countries by almost every economic and financial measure. The fact that the U.K. and Sweden have achieved forward rates and inflation compensation that clearly outperform those in the U.S. despite lagging the U.S. in almost every other respect-including the greatly inferior inflation expectations with which the U.K. and Sweden began the early 1990s—is truly remarkable.

Third, inflation targeting is not a silver bullet that suddenly lowers and stabilizes interest rates and inflation compensation. The U.K. officially adopted inflation targeting in October 1992, but the improvements in far-ahead forward nominal rates and inflation compensation came much later, around the time the Bank of England gained independence, and even then came only gradually. Sweden officially adopted inflation targeting in January 1993 with an effective date of January 1995, but far-ahead forward nominal rates fell gradually throughout the mid-1990s before reaching their current, low levels sometime in 1998. In both countries, the gains in forward nominal rates and inflation compensation came only over time, perhaps because the initial announcement of an inflation targeting regime was regarded with some skepticism by financial markets and only gradually did the feasibility of, and the central bank's commitment to, the new targeting regime become clear.

Fourth, Figure 3 provides direct evidence against the critique by Ball and Sheridan (2003) that there are no visible benefits from inflation targeting once initial conditions and mean reversion are taken into account. Note that the Ball and Sheridan argument would predict that the U.K. and 
Sweden, beginning from their high levels of nominal rates and inflation compensation in the early 1990s, would tend to converge back toward those of the U.S. over the 1990s. In contrast to this prediction, however, we observe that nominal rates and inflation compensation in the U.K. and Sweden actually overtake those in the U.S. in the mid-1990s and then outperform the corresponding U.S. rates for the next ten years. This is a much stronger performance than can be accounted for simply by a tendency for reversion to the mean.

Finally, despite the slowness with which forward rates and inflation compensation fell in both these countries, the rapid response of financial markets to significant economic news can also be seen in Figure 3. Two dates for the U.K. stand out in particular: On September 16, 1992, the U.K. abandoned the Exchange Rate Mechanism, untying the pound from its peg to the other major European currencies, and far-ahead forward nominal interest rates and inflation compensation skyrocketed 200 to $300 \mathrm{bp}$ in a window of just a few days surrounding the announcement. We see a similarly rapid response on May 6, 1997, when Chancellor of the Exchequer Gordon Brown announced that the Bank of England would be granted independence and far-ahead forward nominal rates and inflation compensation plummeted 75 to $100 \mathrm{bp}$ on that one day. ${ }^{29}$ On both dates, financial markets reacted extremely rapidly in just the way that our interpretation of farahead forward rate behavior would suggest that they should.

\footnotetext{
${ }^{29}$ As mentioned previously, this announcement was largely unexpected, particularly its scope—-see British Broadcasting Corporation (1997).
} 
Figure 3

Time Series of Forward Nominal Rates and Inflation Compensation

(a) Far-Ahead Forward Nominal Rates

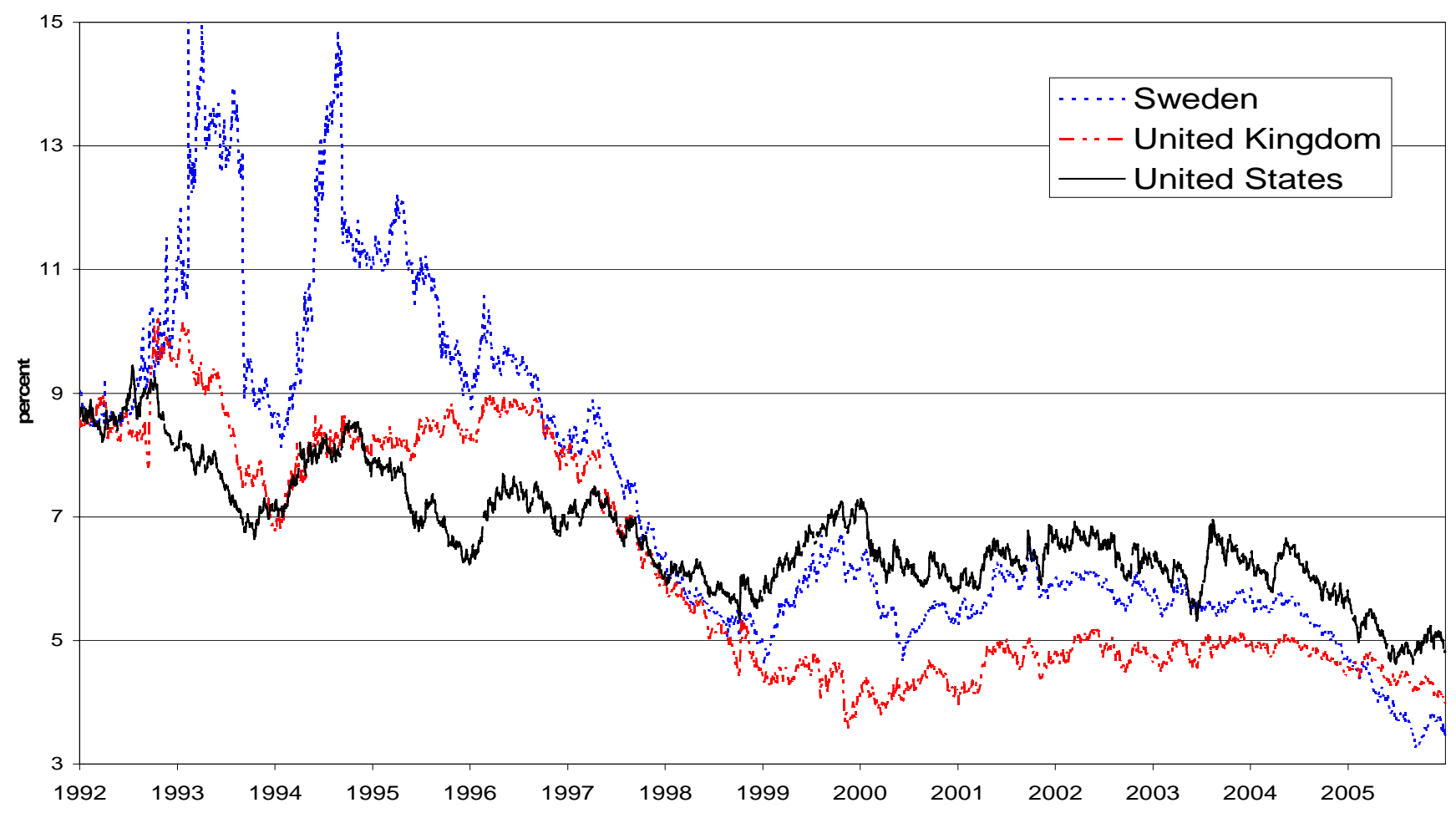

(b) Far-Ahead Forward Inflation Compensation

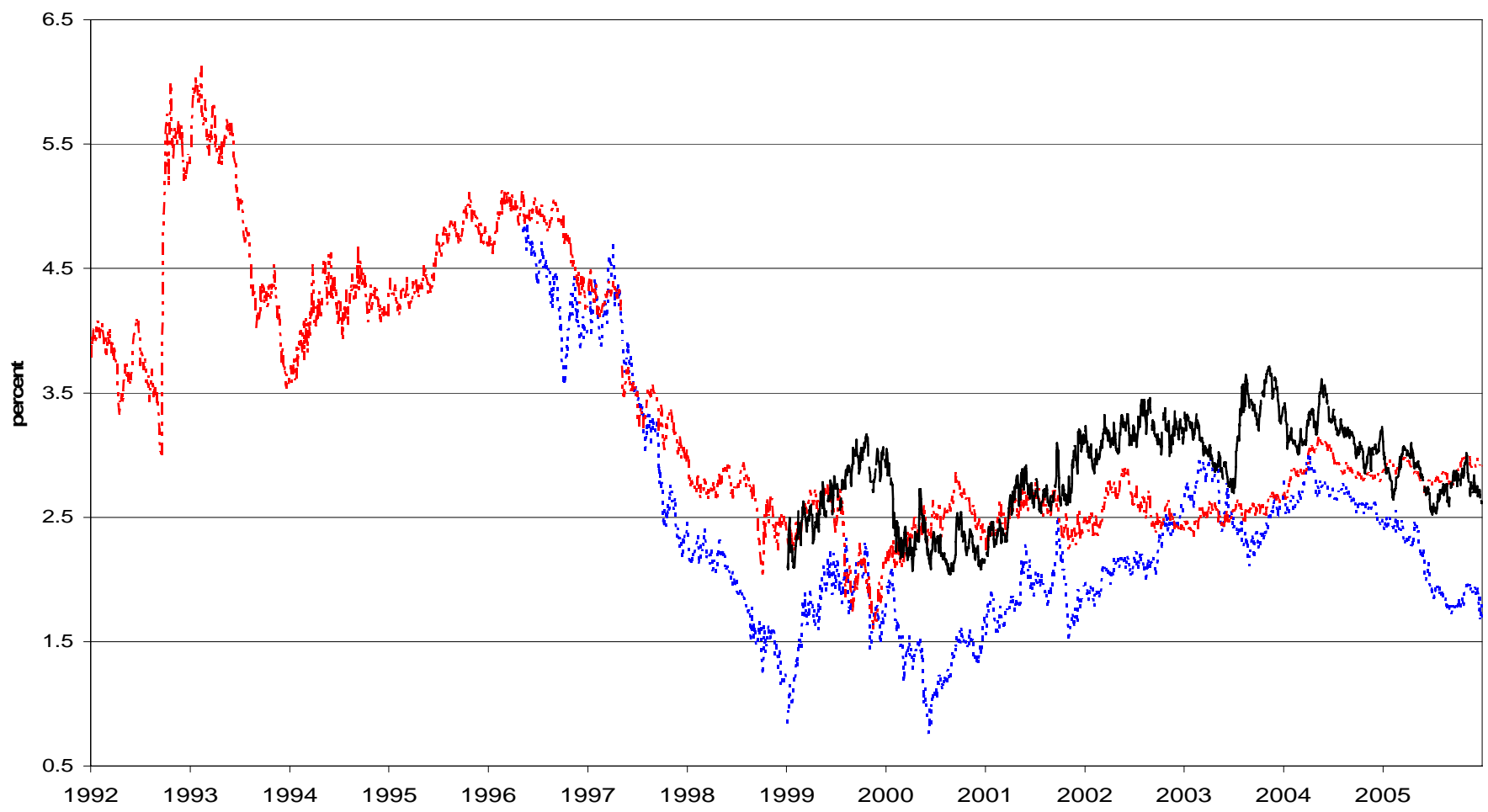




\subsection{Risk Premia}

In interpreting and discussing our results to this point, we have emphasized financial market perceptions of the distribution of long-term inflation outcomes. An alternative explanation of our findings relies not on changes in the physical or objective distribution of long-term inflation outcomes, but rather on the prices that financial markets are willing to pay or accept to take on those risks. In this section, we turn to the possible role of time-varying term or risk premia in explaining our empirical findings.

It should be emphasized at the outset that all of our results and their interpretation do not require the expectations hypothesis $(\mathrm{EH})$ of the term structure to hold. According to the EH, longterm bond yields equal the expected return to rolling over a series of short-term bonds over the same horizon, plus a possibly nonzero term premium that is constant over time. While some authors have found some support for the EH in the data (e.g., Bekaert et al., 2001), a number of prominent studies (e.g., Fama and Bliss, 1987, Campbell and Shiller, 1991) have documented strong violations of the EH over a wide variety of samples and securities, suggesting that the risk, term, liquidity, and/or other premia (often collectively referred to as "risk premia”) embedded in long-term bond yields may in fact vary substantially over time.

However, even if the $\mathrm{EH}$ is violated, our results and their interpretation are essentially unaffected so long as those risk premia vary primarily at lower frequencies — monthly, annual, or business-cycle frequencies, say. In that case, the change in bond yields on any given day effectively differences out the risk premium on that day and leaves changes in market expectations as the primary driver of the one-day change in yields. While there is no reason a priori to think that risk premia should vary only at lower frequencies, the predictors of excess returns on bonds found by the studies above in fact do have this feature, in particular that risk premia vary primarily at business cycle frequencies (Cochrane and Piazzesi, 2005).

Most importantly, however, in order for changes in risk premia to explain our findings, one would have to explain why these premia would vary systematically in precisely the way that we estimate. For example, why would risk premia increase in response to positive news about output 
and employment and decrease in response to negative news, when the results of Cochrane and Piazzesi (2005) and Piazzesi and Swanson (2004) predict exactly the opposite effect? And why would risk premia respond to economic news in the U.S. and in the U.K. prior to 1997, but not in Sweden or in the U.K after 1998? The Swedish bond market in particular is much smaller than the U.S. market, so one might think that liquidity or other risk premia would, if anything, be even more sensitive and even more of an issue in that country than in the U.S.

None of this is meant to imply that time-variation in risk premia has been unimportant over our sample-indeed, a major reason for the unconditional volatility in forward nominal rates and inflation compensation in all three countries in Figure 3 may be changes in risk premia over time. It is just that volatility in risk premia by itself is not sufficient to explain all of our results-one would have to explain why those risk premia would move systematically in response to news in just the way that a partial pass-through from short-term inflation to longer-term inflation would suggest.

We are of course sympathetic to the view that changes in the mean expected long-run inflation rate may not be responsible for our findings so much as changes in the variance, skewness, or other moments of that distribution, but this idea is in fact entirely consistent with our interpretation-namely, that inflation targeting helps to anchor market perceptions of the entire distribution of future long-run inflation outcomes.

\subsection{Sensitivity of U.K. and Swedish Forward Rates to International Economic News}

Our analysis of the sensitivity of far-ahead forward nominal rates and inflation compensation to domestic economic announcements naturally raises the question as to whether those rates behave similarly in the face of international economic announcements. Of course, purely nominal variables such as inflation and inflation compensation should depend entirely on domestic monetary policy, particularly at the longer horizons we are considering, even if domestic real rates are determined by global factors. Thus, we would expect to see a similar degree of anchoring of forward nominal rates and inflation compensation in response to both domestic and international 
economic announcements. Nonetheless, if U.S. and Euro Area economic news rather than domestic news were the primary driver of short-term inflation in Sweden or the U.K. and shortterm inflation had a bearing on the long-term inflation outlook (that is, if long-term expectations in Sweden or the U.K. were not well anchored), then we might see far-ahead forward inflation compensation in those countries react significantly to news from abroad despite an absence of such sensitivity to domestic releases. This argument is testable using U.S. and Euro area surprises together with U.K. and Swedish yield curve data.

Tables 6 and 7 report results for the U.K. from 1993 to 1997 and 1998 to 2005. Short-term interest rates in the U.K. in the earlier period (Table 6) respond significantly to only a few U.S. economic announcements - capacity utilization, the core CPI, and the NAPM survey. Nonetheless, in all three of these cases, we estimate a very substantial degree of pass-through to far-ahead forward nominal rates and inflation compensation and overwhelmingly reject the hypothesis of no significant relationship, consistent with our earlier findings for the response of U.K. rates to domestic economic announcements. Note that, although the coefficients on unemployment in the forward rate regressions in Table 6 are significant as well, they do not enter significantly in the short-rate regressions and they enter with a sign opposite from what one would expect if there were pass-through from short-term to long-term inflation, which leads us to regard those coefficients with skepticism.

By contrast, in the later period for the U.K. (Table 7), far-ahead forward inflation compensation shows much less sensitivity to economic news, with only one out of the fourteen coefficients (on the NAPM survey) in the last column being statistically significant. This is despite the fact that many more coefficients in the short-rate regression are significant over this later sample (the coefficients on U.S. capacity utilization, initial claims, NAPM, nonfarm payrolls, retail sales, and monetary policy). It is noteworthy that far-ahead forward nominal interest rates respond significantly to three of these fourteen releases, yet only in the one case does this sensitivity appear to be due to the inflation compensation component rather than changes in real rates. The evidence in the table is thus consistent with the view that long-term British real rates are at least partly 
determined by global factors (and thus that the sensitivity of British real rates to U.S. news is due, perhaps, to information in these releases that markets view as shedding light on global long-term real rate prospects) while British inflation expectations and inflation compensation over the period remained, for the most part, well anchored.

Table 8 repeats the analysis for Sweden. Short rates in Sweden respond significantly to only two of the fourteen U.S. and Euro area economic announcements in the table. Of these, one (the NAPM survey) leads to significant movements in far-ahead forward nominal rates and inflation compensation. Interestingly, this is the same (and the only) statistic that led far-ahead forward inflation compensation in the U.K. to move over the 1998-2005 period. There is some evidence that U.S. retail sales lead to movements in Swedish forward nominal rates and inflation compensation, but because this statistic has no effect on Swedish short rates it is difficult to interpret these longer-term responses as indicative of a pass-through of short-term inflation to the longer-term inflation outlook. The U.S. nonfarm payrolls release also seems to move Swedish forward nominal and real interest rates, as it did in the U.K. (which is again consistent with a global story for the determination of long-term real interest rates), but there is no significant response of Swedish inflation compensation to this release, also as in the U.K. Thus, our results for Sweden mirror very closely those in the post-1998 U.K.: with the exception of the U.S. NAPM release, the results are consistent with the view that long-term inflation expectations in Sweden have been relatively well anchored in response to economic news. ${ }^{30}$

\footnotetext{
${ }^{30}$ The significance of the NAPM release for far-ahead forward inflation compensation in the U.K. and Sweden, and the importance of both the NAPM and nonfarm payrolls releases for far-ahead forward real rates in those countries, are interesting and pose worthwhile questions for future research. The nonfarm payrolls and NAPM releases occur early in the month and tend to elicit some of the largest financial market reactions in the U.S., as can be seen in Tables 1 and 2 . Nonetheless, why these releases and no others would move far-ahead forward real rates around the globe is something of a puzzle, which more data might help to illuminate.
} 


\section{Table 6}

U.K. Forward Rate Responses to International Economic News (1993-April 1997)

\begin{tabular}{|c|c|c|c|c|}
\hline & $\begin{array}{l}\text { 1-year } \\
\text { Nominal } \\
\text { Rate }\end{array}$ & $\begin{array}{l}\text { 1-year Forward } \\
\text { Nominal Rate } \\
\text { ending in } 10 \text { yrs }\end{array}$ & $\begin{array}{l}\text { 1-year Forward } \\
\text { Real Rate } \\
\text { ending in } 10 \text { yrs }\end{array}$ & $\begin{array}{c}\text { 1-year Forward } \\
\text { Inflation } \\
\text { Compensation } \\
\text { ending in } 10 \text { yrs }\end{array}$ \\
\hline $\begin{array}{r}\text { U.S. Capacity } \\
\text { Utilization }\end{array}$ & $\begin{array}{l}\text { 1.61** } \\
(3.68)\end{array}$ & $\begin{array}{l}\text { 2.44** } \\
(2.91)\end{array}$ & $\begin{array}{c}0.25 \\
(1.17)\end{array}$ & $\begin{array}{l}\text { 2.19** } \\
(2.99)\end{array}$ \\
\hline $\begin{array}{r}\text { U.S. Consumer } \\
\text { Confidence }\end{array}$ & $\begin{array}{l}-0.17 \\
(-0.27)\end{array}$ & $\begin{array}{c}0.35 \\
(0.37)\end{array}$ & $\begin{array}{c}0.18 \\
(1.03)\end{array}$ & $\begin{array}{c}0.17 \\
(0.19)\end{array}$ \\
\hline $\begin{array}{r}\text { U.S. core Cons. } \\
\text { Price Index }\end{array}$ & $\begin{array}{l}\text { 1.15* } \\
(2.04)\end{array}$ & $\begin{array}{l}2.29 * * \\
(2.86)\end{array}$ & $\begin{array}{c}-0.11 \\
(-0.36)\end{array}$ & $\begin{array}{l}2.40 * * \\
(3.79)\end{array}$ \\
\hline $\begin{array}{r}\text { U.S. real GDP } \\
\text { (advance) }\end{array}$ & $\begin{array}{c}-1.77 \\
(-1.79)\end{array}$ & $\begin{array}{c}-2.62 \\
(-1.04)\end{array}$ & $\begin{array}{c}-0.45 \\
(-0.75)\end{array}$ & $\begin{array}{c}-2.17 \\
(-1.11)\end{array}$ \\
\hline $\begin{array}{r}\text { U.S. Initial } \\
\text { Jobless Claims }\end{array}$ & $\begin{array}{c}-0.60 \\
(-1.86)\end{array}$ & $\begin{array}{c}-0.19 \\
(-0.33)\end{array}$ & $\begin{array}{c}0.05 \\
(0.33)\end{array}$ & $\begin{array}{c}-0.24 \\
(-0.52)\end{array}$ \\
\hline $\begin{array}{r}\text { U.S. NAPM/ISM } \\
\text { Manufacturing }\end{array}$ & $\begin{array}{l}\text { 1.96** } \\
(3.12)\end{array}$ & $\begin{array}{l}2.67 * \\
(2.58)\end{array}$ & $\begin{array}{l}\text { 0.71* } \\
(2.43)\end{array}$ & $\begin{array}{l}\text { 1.96* } \\
(2.20)\end{array}$ \\
\hline $\begin{array}{r}\text { U.S. New Home } \\
\text { Sales }\end{array}$ & $\begin{array}{l}-0.92 \\
(-1.43)\end{array}$ & $\begin{array}{c}0.22 \\
(0.16)\end{array}$ & $\begin{array}{c}0.32 \\
(0.70)\end{array}$ & $\begin{array}{c}-0.10 \\
(-0.09)\end{array}$ \\
\hline $\begin{array}{r}\text { U.S. Nonfarm } \\
\text { Payrolls }\end{array}$ & $\begin{array}{c}0.94 \\
(1.50)\end{array}$ & $\begin{array}{c}1.69 \\
(1.41)\end{array}$ & $\begin{array}{c}0.70 \\
(0.99)\end{array}$ & $\begin{array}{c}0.99 \\
(1.49)\end{array}$ \\
\hline $\begin{array}{r}\text { U.S. Retail Sales } \\
\text { (ex autos) }\end{array}$ & $\begin{array}{c}1.09 \\
(1.75)\end{array}$ & $\begin{array}{c}2.39 \\
(1.38)\end{array}$ & $\begin{array}{c}0.83 \\
(1.71)\end{array}$ & $\begin{array}{c}1.56 \\
(1.13)\end{array}$ \\
\hline $\begin{array}{r}\text { U.S. } \\
\text { Unemployment }\end{array}$ & $\begin{array}{c}0.49 \\
(0.63)\end{array}$ & $\begin{array}{l}3.38 * * \\
(3.08)\end{array}$ & $\begin{array}{c}0.22 \\
(0.36)\end{array}$ & $\begin{array}{l}3.16 * * \\
(4.17)\end{array}$ \\
\hline $\begin{array}{r}\text { U.S. Monetary } \\
\text { Policy }\end{array}$ & $\begin{array}{c}0.09 \\
(0.97)\end{array}$ & $\begin{array}{c}0.13 \\
(1.09)\end{array}$ & $\begin{array}{l}\text { 0.11* } \\
(2.16)\end{array}$ & $\begin{array}{c}0.02 \\
(0.17)\end{array}$ \\
\hline \# Observations & 606 & 606 & 606 & 606 \\
\hline$R^{2}$ & .20 & .11 & .06 & .13 \\
\hline Joint test p-value & $.0000 * *$ & $.0000 * *$ & .086 & $.0000 * *$ \\
\hline
\end{tabular}




\section{Table 7}

U.K. Forward Rate Responses to International Economic News (July 1998-2005)

\begin{tabular}{|c|c|c|c|c|}
\hline & $\begin{array}{c}\text { 1-year } \\
\text { Nominal Rate }\end{array}$ & $\begin{array}{l}\text { 1-year Forward } \\
\text { Nominal Rate } \\
\text { ending in } 10 \text { yrs }\end{array}$ & $\begin{array}{l}\text { 1-year Forward } \\
\text { Real Rate } \\
\text { ending in } 10 \text { yrs }\end{array}$ & $\begin{array}{c}\text { 1-year Forward } \\
\text { Inflation } \\
\text { Compensation } \\
\text { ending in } 10 \text { yrs }\end{array}$ \\
\hline $\begin{array}{r}\text { U.S. Capacity } \\
\text { Utilization }\end{array}$ & $\begin{array}{l}\mathbf{0 . 8 6} * \\
(1.97)\end{array}$ & $\begin{array}{c}0.74 \\
(1.37)\end{array}$ & $\begin{array}{c}0.24 \\
(0.80)\end{array}$ & $\begin{array}{c}0.50 \\
(1.17)\end{array}$ \\
\hline $\begin{array}{l}\text { U.S. Consumer } \\
\text { Confidence }\end{array}$ & $\begin{array}{c}0.51 \\
(1.12)\end{array}$ & $\begin{array}{c}0.81 \\
(1.45)\end{array}$ & $\begin{array}{c}0.46 \\
(1.49)\end{array}$ & $\begin{array}{c}0.35 \\
(0.79)\end{array}$ \\
\hline $\begin{array}{l}\text { U.S. core Cons. } \\
\text { Price Index }\end{array}$ & $\begin{array}{c}0.48 \\
(1.06)\end{array}$ & $\begin{array}{c}-0.16 \\
(-0.29)\end{array}$ & $\begin{array}{c}0.17 \\
(0.56)\end{array}$ & $\begin{array}{c}-0.33 \\
(-0.75)\end{array}$ \\
\hline $\begin{array}{r}\text { U.S. real GDP } \\
\text { (advance) }\end{array}$ & $\begin{array}{c}0.27 \\
(0.40)\end{array}$ & $\begin{array}{c}0.60 \\
(0.71)\end{array}$ & $\begin{array}{c}0.45 \\
(0.97)\end{array}$ & $\begin{array}{c}0.14 \\
(0.21)\end{array}$ \\
\hline $\begin{array}{l}\text { U.S. Initial } \\
\text { Jobless Claims }\end{array}$ & $\begin{array}{c}-0.43^{*} \\
(-2.08)\end{array}$ & $\begin{array}{l}-0.50 \\
(-1.95)\end{array}$ & $\begin{array}{c}-0.23 \\
(-1.59)\end{array}$ & $\begin{array}{c}-0.27 \\
(-1.34)\end{array}$ \\
\hline $\begin{array}{r}\text { U.S. NAPM/ISM } \\
\text { Manufacturing }\end{array}$ & $\begin{array}{l}1.58 * * \\
(3.63)\end{array}$ & $\begin{array}{l}2.61 * * \\
(4.85)\end{array}$ & $\begin{array}{l}\text { 1.03** } \\
(3.46)\end{array}$ & $\begin{array}{l}\text { 1.58** } \\
(3.69)\end{array}$ \\
\hline $\begin{array}{r}\text { U.S. New Home } \\
\text { Sales }\end{array}$ & $\begin{array}{c}0.26 \\
(0.66)\end{array}$ & $\begin{array}{c}0.07 \\
(0.15)\end{array}$ & $\begin{array}{c}0.33 \\
(1.22)\end{array}$ & $\begin{array}{c}-0.25 \\
(-0.66)\end{array}$ \\
\hline $\begin{array}{r}\text { U.S. Nonfarm } \\
\text { Payrolls }\end{array}$ & $\begin{array}{l}\mathbf{1 . 5 8 * *} \\
(3.30)\end{array}$ & $\begin{array}{l}2.02 * * \\
(3.42)\end{array}$ & $\begin{array}{l}1.37 * * \\
(4.16)\end{array}$ & $\begin{array}{c}0.66 \\
(1.39)\end{array}$ \\
\hline $\begin{array}{r}\text { U.S. Retail Sales } \\
\text { (ex autos) }\end{array}$ & $\begin{array}{l}\mathbf{1 . 0 9 * *} \\
(2.69)\end{array}$ & $\begin{array}{c}0.31 \\
(0.62)\end{array}$ & $\begin{array}{c}0.52 \\
(1.86)\end{array}$ & $\begin{array}{c}-0.21 \\
(-0.51)\end{array}$ \\
\hline $\begin{array}{r}\text { U.S. } \\
\text { Unemployment }\end{array}$ & $\begin{array}{c}0.06 \\
(0.12)\end{array}$ & $\begin{array}{c}0.42 \\
(0.69)\end{array}$ & $\begin{array}{c}0.50 \\
(1.48)\end{array}$ & $\begin{array}{c}-0.08 \\
(-0.17)\end{array}$ \\
\hline $\begin{array}{r}\text { U.S. Monetary } \\
\text { Policy }\end{array}$ & $\begin{array}{c}\mathbf{0 . 1 5} * \\
(2.41)\end{array}$ & $\begin{array}{c}-0.10 \\
(-1.33)\end{array}$ & $\begin{array}{c}0.01 \\
(0.32)\end{array}$ & $\begin{array}{c}-0.12 \\
(-1.90)\end{array}$ \\
\hline $\begin{array}{r}\text { Euro Area } \\
\text { Indust. Productn }\end{array}$ & $\begin{array}{c}0.85 \\
(1.38)\end{array}$ & $\begin{array}{c}-0.18 \\
(-0.24)\end{array}$ & $\begin{array}{c}-0.06 \\
(-0.14)\end{array}$ & $\begin{array}{c}-0.12 \\
(-0.21)\end{array}$ \\
\hline $\begin{array}{r}\text { Euro Area } \\
\text { Retail Trade }\end{array}$ & $\begin{array}{c}0.50 \\
(0.78)\end{array}$ & $\begin{array}{c}-0.20 \\
(-0.26)\end{array}$ & $\begin{array}{c}0.01 \\
(0.02)\end{array}$ & $\begin{array}{c}-0.21 \\
(-0.34)\end{array}$ \\
\hline $\begin{array}{r}\text { Euro Area } \\
\text { Monetary Policy }\end{array}$ & $\begin{array}{c}-0.20 \\
(-0.72)\end{array}$ & $\begin{array}{c}0.33 \\
(0.95)\end{array}$ & $\begin{array}{c}0.16 \\
(0.81)\end{array}$ & $\begin{array}{c}0.17 \\
(0.62)\end{array}$ \\
\hline \# Observations & 1180 & 1180 & 1180 & 1180 \\
\hline$R^{2}$ & .15 & .05 & .04 & .03 \\
\hline Joint test $p$-value & $.0000 * *$ & $.0000 * *$ & $.0001 * *$ & $.047 *$ \\
\hline
\end{tabular}

Notes: The same notes as in Table 4 and Table 6 apply. See text for details. 


\section{Table 8}

Swedish Forward Rate Responses to International Economic News (1996-2005)

\begin{tabular}{|c|c|c|c|c|}
\hline & $\begin{array}{c}\text { 1-year } \\
\text { Nominal Rate }\end{array}$ & $\begin{array}{l}\text { 1-year Forward } \\
\text { Nominal Rate } \\
\text { ending in } 10 \text { yrs }\end{array}$ & $\begin{array}{l}\text { 1-year Forward } \\
\text { Real Rate } \\
\text { ending in } 10 \text { yrs }\end{array}$ & $\begin{array}{c}\text { 1-year Forward } \\
\text { Inflation } \\
\text { Compensation } \\
\text { ending in } 10 \text { yrs }\end{array}$ \\
\hline $\begin{array}{r}\text { U.S. Capacity } \\
\text { Utilization }\end{array}$ & $\begin{array}{c}1.01 \\
(1.57)\end{array}$ & $\begin{array}{c}0.07 \\
(0.15)\end{array}$ & $\begin{array}{c}-0.22 \\
(-0.95)\end{array}$ & $\begin{array}{c}0.29 \\
(0.62)\end{array}$ \\
\hline $\begin{array}{r}\text { U.S. Consumer } \\
\text { Confidence }\end{array}$ & $\begin{array}{l}1.42 * * \\
(2.74)\end{array}$ & $\begin{array}{c}-0.09 \\
(-0.21)\end{array}$ & $\begin{array}{c}0.17 \\
(1.16)\end{array}$ & $\begin{array}{c}-0.26 \\
(-0.60)\end{array}$ \\
\hline $\begin{array}{l}\text { U.S. core Cons. } \\
\text { Price Index }\end{array}$ & $\begin{array}{l}-0.20 \\
(-0.36)\end{array}$ & $\begin{array}{c}0.78 \\
(1.59)\end{array}$ & $\begin{array}{c}0.03 \\
(0.11)\end{array}$ & $\begin{array}{c}0.75 \\
(1.63)\end{array}$ \\
\hline $\begin{array}{r}\text { U.S. real GDP } \\
\text { (advance) }\end{array}$ & $\begin{array}{c}-0.20 \\
(-0.26)\end{array}$ & $\begin{array}{c}0.32 \\
(0.42)\end{array}$ & $\begin{array}{c}0.22 \\
(1.02)\end{array}$ & $\begin{array}{c}0.10 \\
(0.13)\end{array}$ \\
\hline $\begin{array}{r}\text { U.S. Initial } \\
\text { Jobless Claims }\end{array}$ & $\begin{array}{l}-0.36 \\
(-1.23)\end{array}$ & $\begin{array}{l}-0.20 \\
(-0.82)\end{array}$ & $\begin{array}{c}-0.04 \\
(-0.34)\end{array}$ & $\begin{array}{l}-0.16 \\
(-0.72)\end{array}$ \\
\hline $\begin{array}{r}\text { U.S. NAPM/ISM } \\
\text { Manufacturing }\end{array}$ & $\begin{array}{l}3.91 * * \\
(3.37)\end{array}$ & $\begin{array}{l}2.56 * * \\
(4.64)\end{array}$ & $\begin{array}{l}\text { 0.72** } \\
(3.79)\end{array}$ & $\begin{array}{l}\text { 1.83** } \\
(3.55)\end{array}$ \\
\hline $\begin{array}{r}\text { U.S. New Home } \\
\text { Sales }\end{array}$ & $\begin{array}{c}0.77 \\
(1.24)\end{array}$ & $\begin{array}{c}0.39 \\
(0.77)\end{array}$ & $\begin{array}{l}-0.32 \\
(1.26)\end{array}$ & $\begin{array}{c}0.70 \\
(1.56)\end{array}$ \\
\hline $\begin{array}{r}\text { U.S. Nonfarm } \\
\text { Payrolls }\end{array}$ & $\begin{array}{c}1.14 \\
(1.26)\end{array}$ & $\begin{array}{l}\mathbf{1 . 5 7 * *} \\
(2.61)\end{array}$ & $\begin{array}{l}\mathbf{0 . 8 7 *} \\
(2.39)\end{array}$ & $\begin{array}{c}0.70 \\
(1.09)\end{array}$ \\
\hline $\begin{array}{r}\text { U.S. Retail Sales } \\
\text { (ex autos) }\end{array}$ & $\begin{array}{c}0.59 \\
(1.04)\end{array}$ & $\begin{array}{c}1.03 * \\
(2.41)\end{array}$ & $\begin{array}{c}0.11 \\
(0.43)\end{array}$ & $\begin{array}{c}\mathbf{0 . 9 1} * \\
(2.31)\end{array}$ \\
\hline $\begin{array}{r}\text { U.S. } \\
\text { Unemployment }\end{array}$ & $\begin{array}{c}-0.58 \\
(-0.66)\end{array}$ & $\begin{array}{c}-0.78 \\
(-1.24)\end{array}$ & $\begin{array}{c}0.36 \\
(1.26)\end{array}$ & $\begin{array}{c}-1.14 \\
(-1.86)\end{array}$ \\
\hline $\begin{array}{r}\text { U.S. Monetary } \\
\text { Policy }\end{array}$ & $\begin{array}{c}0.25 \\
(1.63)\end{array}$ & $\begin{array}{c}-0.07 \\
(-0.58)\end{array}$ & $\begin{array}{c}0.01 \\
(0.11)\end{array}$ & $\begin{array}{c}-0.07 \\
(-0.76)\end{array}$ \\
\hline $\begin{array}{r}\text { Euro Area } \\
\text { Indust. Productn }\end{array}$ & $\begin{array}{c}-0.14 \\
(-0.20)\end{array}$ & $\begin{array}{c}0.10 \\
(0.17)\end{array}$ & $\begin{array}{c}0.38 \\
(0.81)\end{array}$ & $\begin{array}{c}-0.29 \\
(-0.64)\end{array}$ \\
\hline $\begin{array}{r}\text { Euro Area } \\
\text { Retail Trade }\end{array}$ & $\begin{array}{c}0.58 \\
(0.90)\end{array}$ & $\begin{array}{c}1.30 \\
(1.81)\end{array}$ & $\begin{array}{c}0.62 \\
(1.38)\end{array}$ & $\begin{array}{c}0.68 \\
(1.03)\end{array}$ \\
\hline $\begin{array}{r}\text { Euro Area } \\
\text { Monetary Policy }\end{array}$ & $\begin{array}{c}-0.02 \\
(-0.03)\end{array}$ & $\begin{array}{c}0.33 \\
(0.70)\end{array}$ & $\begin{array}{c}0.30 \\
(1.63)\end{array}$ & $\begin{array}{c}0.03 \\
(0.07)\end{array}$ \\
\hline \# Observations & 1305 & 1305 & 1305 & 1305 \\
\hline$R^{2}$ & .08 & .04 & .03 & .02 \\
\hline Joint test p-value & $.001 * *$ & $.0000 * *$ & $.006 * *$ & $.003 * *$ \\
\hline
\end{tabular}

Notes: The same notes as in Table 5 apply. Regressions also include Swedish economic news releases listed in Table 5 (coefficients not reported since they are very similar to that table). Joint test p-value is for the hypothesis that all 15 coefficients listed above are zero. See text for details. 


\section{Conclusions}

Does inflation targeting help to anchor private sector perceptions of the future distribution of longrun inflation outcomes? We find much evidence that it does. In contrast to previous studies using quarterly or even semiannual data, we have presented evidence from over three thousand daily observations of long-term bond yield responses to economic news in the U.S., U.K., and Sweden that support this conclusion. Far-ahead forward nominal rates and inflation compensation in the U.S. and U.K. (prior to Bank of England independence) respond significantly to economic news while those in the U.K. after central bank independence and in Sweden exhibit very little such sensitivity.

Our results have potentially important implications for the U.S. Despite the generally superb performance of the U.S. economy and U.S. monetary policy in the 1990s and 2000s, we find that the gains realized in the U.K. and Sweden were-with respect to long-term interest rates and inflation compensation at least—even greater. In particular, the Federal Reserve's informal approach to a long-run inflation objective does not seem to have anchored the private sector's longrun inflation views to the same extent that the formal inflation targeting frameworks in the U.K. and Sweden did. This comparison is all the more remarkable given the greatly inferior inflation expectations that existed in the U.K. and Sweden, relative to the U.S., in the early 1990s.

Although some might argue that the sensitivity we estimate is only a few basis points per announcement, this argument misses the forest for the trees, for two reasons. First, the effects of these announcements should be considered jointly, rather than individually—even though a single monthly data release is just one very noisy indicator of the state of the U.S. economy, the information content of those releases is quite significant when they are considered jointly and over time. Thus, the few basis points per announcement that we estimate often cumulate, over the course of just a few months, to large and significant changes in long-term interest rates, as any casual observer of financial markets is well aware. ${ }^{31}$ Second, the sensitivity of far-ahead forward

\footnotetext{
${ }^{31}$ More technically, the variance of a unit root process increases linearly over time. U.S. economic activity and inflation are persistent enough that the variance of the cumulative sum of monthly data releases increases essentially
} 
nominal rates and inflation compensation to economic news that we estimate is almost as large as the sensitivity of short-term interest rates to these announcements. Because it is widely recognized that short-term interest rates should and do respond substantially to current output and inflation and to incoming news about these variables, it follows that the sensitivity of far-ahead forward nominal rates and inflation compensation to economic news that we estimate is just as substantial.

Finally, although we have not shown in this paper that there any advantages, either qualitatively or quantitatively, to the anchoring of long-term inflation expectations, macroeconomic and finance theory suggest that there should be several: for example, less volatile and less persistent inflation even in the short run and a greater ability of the central bank to control inflation (e.g., Woodford, 2003, Svensson and Woodford, 2003, Orphanides and Williams, 2005); a reduced chance of a 1970’s-style “expectations trap” for inflation (e.g., Albanesi, Chari, and Christiano, 2003) or an imperfect information-driven “inflation scare” (e.g., Orphanides and Williams, 2005); less volatile fluctuations in output (Bernanke, 2004); and less volatile long-term nominal interest rates that would improve the efficiency of investment decisions (e.g., Ingersoll and Ross, 1992). To the extent that these benefits are important in practice as well as in principle, there are reasons to think that, with a more explicit inflation objective, U.S. monetary policy and economic performance could be improved even beyond the successes of the past twenty years.

linearly in the near term. Thus the impact of these announcements on long-term interest rates will have a tendency to cumulate strongly in the near term with a variance that grows essentially linearly with each announcement. 


\section{Data Appendix}

Data on U.S. macroeconomic statistical releases and forecasts were collected by Money Market Services up through July 2003, when that company merged with a larger financial institution. Subsequent to July 2003, the same survey was produced again by Action Economics. These data can be purchased from Haver Analytics as part of the "MMS" series of data at http://www.haver.com.

For the U.K., we also obtained MMS data for the U.K. from Haver Analytics. For the U.K., many of the MMS series are reported both as month-on-month and year-on-year changes, so this presents an issue in terms of which version of each statistic to use in our analysis. If one version contained many more observations than the other; then we used the version that had more observations - in every case, this turned out to be the year-on-year version (for some series, the month-on-month version was not collected or reported by MMS at all). When the number of observations was similar across the two versions, we used the year-on-year changes by default, because those were the versions that were more often available in general and those are the versions that are reported in the headlines of the British press. In any case, we have verified that whether we use the month-on-month or year-on-year changes for the statistical releases has essentially no impact on our results.

For Sweden, we obtained data on statistical releases and private sector forecasts from Bloomberg Financial Services. Bloomberg offers forecasts of a greater number of Swedish and Euro area statistics than Money Market Services and were more readily available to us. Bloomberg also offers these data for the U.S. and U.K. as well, although they do not go as far back as the MMS data (about 1996 for Bloomberg vs. 1985 for MMS-US and 1993 for MMS-UK), but the two data sources agree very closely when they overlap. As in the U.K., when there is a choice between the year-on-year and month-on-month versions of a statistical release, we favor the year-on-year version unless there is more data available for the month-on-month version. Also as in the U.K., whether we use the month-onmonth or year-on-year versions has very little effect on our results.

Finally, we investigate the sensitivity of U.K. and Swedish interest rates to Euro Area data releases. As for Sweden, we obtained data on statistical releases and private sector forecasts for the Euro Area from Bloomberg. However, for many Euro Area variables, the individual country components are published several weeks prior to the release of the Euro Area aggregate, so that the Bloomberg consensus projection consistently matches the actual release. Thus, we are only able to use two Euro Area macroeconomic data releases that exhibit non-trivial surprises: industrial production and retail trade. Of course, because the publication of these Euro Area series was only initiated a few years ago, the impact of surprises in these variables cannot be assessed for U.K. data over the 1993-97 period.

The exact statistics we use for all of these countries, including MMS and Bloomberg mnemonics, are reported in the following tables:

\section{United States}

\begin{tabular}{|l|l|}
\hline Name & MMS/Haver Mnemonic \\
\hline Capacity Utilization & $\{\mathrm{L}, \mathrm{M}\} 111 \mathrm{CU}$ \\
\hline Consumer Confidence & $\{\mathrm{L}, \mathrm{M}\} 111 \mathrm{CNCF}$ \\
\hline core Consumer Price Index & $\{\mathrm{L}, \mathrm{M}\} 111 \mathrm{CPCM}$ \\
\hline real GDP (advance) & $\{\mathrm{L}, \mathrm{M}\} 111 \mathrm{GPAA}$ \\
\hline Initial Jobless Claims & $\{\mathrm{L}, \mathrm{M}\} 111 \mathrm{IC}$ \\
\hline NAPM/ISM Manufacturing & $\{\mathrm{L}, \mathrm{M}\} 111 \mathrm{PMIF}$ \\
\hline New Home Sales & $\{\mathrm{L}, \mathrm{M}\} 111 \mathrm{HNST}$ \\
\hline Nonfarm Payrolls & $\{\mathrm{L}, \mathrm{M}\} 111 \mathrm{ED}$ \\
\hline Retail Sales (ex autos) & $\{\mathrm{L}, \mathrm{M}\} 111 \mathrm{RSXM}$ \\
\hline Unemployment Rate & $\{\mathrm{L}, \mathrm{M}\} 111 \mathrm{EUR}$ \\
\hline
\end{tabular}

\section{United Kingdom}

\begin{tabular}{|l|l|}
\hline Name & MMS/Haver Mnemonic \\
\hline Average Earnings & $\{\mathrm{L}, \mathrm{M}\} 112 \mathrm{AEPY}$ \\
\hline real GDP (preliminary) & $\{\mathrm{L}, \mathrm{M}\} 112 \mathrm{GPAY}$ \\
\hline Manufacturing Industrial Production & $\{\mathrm{L}, \mathrm{M}\} 112 \mathrm{MFPY}$ \\
\hline Producer Price Index & $\{\mathrm{L}, \mathrm{M}\} 112 \mathrm{PPIY}$ \\
\hline Retail Price Index excl Mortgage Interest & $\{\mathrm{L}, \mathrm{M}\} 112 \mathrm{RPXY}$ \\
\hline Retail Sales & $\{\mathrm{L}, \mathrm{M}\} 112 \mathrm{RSRY}$ \\
\hline
\end{tabular}




\section{Sweden}

\begin{tabular}{|l|l|}
\hline Name & Bloomberg Mnemonic \\
\hline Consumer Price Index & swcpyoy \\
\hline core Consumer Price Index & swcpundy \\
\hline real GDP (preliminary) & swgdpwyy \\
\hline Industrial Production & swipnsyy \\
\hline Producer Price Index & swppiyoy \\
\hline Retail Sales & swrsiyoy \\
\hline Unemployment & swue \\
\hline
\end{tabular}

\section{Euro Area}

\begin{tabular}{|l|l|}
\hline Name & Bloomberg Mnemonic \\
\hline Euro Area Industrial Production & euipemuy \\
\hline Euro Area Retail Trade & eurtezy \\
\hline
\end{tabular}

\section{Monetary Policy Surprises}

For the U.S., we measure monetary policy surprises using federal funds futures, which provide high-quality, virtually continuous measures of market expectations for the federal funds rate. Gürkaynak, Sack, and Swanson (2002) show that, among the many possible financial market instruments that potentially reflect expectations of monetary policy, federal funds futures are the best predictor of future policy actions. The federal funds futures contract for a given month settles at the end of the month based on the average federal funds rate that was realized over the course of that month. Thus, daily changes in the current-month futures rate reflect revisions to the market's expectations for the federal funds rate over the remainder of the month. (Our results are essentially unchanged if we instead use the change in a 3-month interest rate, such as the 3-month Treasury bill rate, on the days of monetary policy announcements.) As explained in Kuttner (2001) and Gürkaynak et al. (2002), the change in the current month's contract rate on the day of a Federal Open Market Committee (FOMC) announcement can be scaled up to account for the timing of the announcement within the month to provide a measure of the surprise component of the FOMC decision. ${ }^{32}$ We compute the surprise component associated with every FOMC meeting and inter-meeting policy action by the FOMC over our sample. $^{33}$

For the United Kingdom, we do not have futures data for the policy rate of the Bank of England, so we measure monetary policy surprises using the change in the 3-month government bill rate (obtained from the Bank of England's web site) on the days of Bank of England monetary policy announcements. The change in the 3-month rate on these days reflects changes in financial market expectations about the current and future course of monetary policy over the subsequent 3 months. While this is not the same as the shorter horizon one would obtain from a very near-term futures contract, it is nonetheless an excellent measure of the change in the near-term monetary policy environment. When the one-day change in the government bill rate isn't available (this is the case for many observations in the pre-1997 period), we use the two-day change in the spot 3-month sterling London Interbank Offer Rate (LIBOR). (The LIBOR rate is quoted at around $11 \mathrm{am}$ London time and we do not always know at what time the monetary policy announcement was made to the public, so we must use a two-day window to be sure of bracketing the announcement.) Prior to May 1997, the only monetary policy announcements that we have are actual changes in the policy rate by the Bank of England, the dates of which we obtained from the Bank of England's web site. After May 1997, there are well-defined announcement dates in the event of no change in policy rate as well. For comparability to the pre-1997 period, we continue to focus only on changes in the policy rate from 1998-2005, but our results are very similar if we use all monetary policy announcements (including those with no rate change) in the post-1998 period.

\footnotetext{
${ }^{32}$ In order to avoid very large scale factors, if the monetary policy announcement occurs in the last seven days of the month, we use the next-month contract rate instead of scaling up the current-month contract rate.

${ }^{33}$ There is one exception in that we exclude the intermeeting 50bp easing on September 17, 2001, because financial markets were closed for several days prior to that action and because that easing was a response to a large exogenous shock to the U.S. economy, and we would have difficulty disentangling the effect of the monetary policy action from the effect of the shock itself on financial markets that day.
} 
For Sweden, we also do not have futures data on the monetary policy instrument and use the change in the 3month Swedish Government Bill rate on the days of Riksbank monetary policy announcements, which we obtained from the Swedish Riksbank’s web site.

For the Euro Area, we use the change in the spot 3-month Euribor rate in Frankfurt. Note that, for the Euro Area, we only include monetary policy committee meeting dates on which an interest rate decision was considered. 


\section{References}

Adolfson, Malin, Stefan Laséen, Jesper Lindé, and Mattias Villani, 2006. "Evaluating an Estimated New Keynesian Small Open Economy Model,” Journal of Economic Dynamics and Control, forthcoming.

Albanesi, Stefania, V.V. Chari, and Lawrence J. Christiano, 2003. "Expectations Traps and Monetary Policy.” Review of Economic Studies 70, 715-41.

Altig, David, Lawrence Christiano, Martin Eichenbaum, and Jesper Lindé, 2005. "The Role of Monetary Policy in the Propagation of Technology Shocks,” unpublished manuscript, Northwestern University.

Andersen, Torben G., Tim Bollerslev, Francis X. Diebold, and Clara Vega, 2003. "Micro Effects of Macro Announcements: Real-Time Price Discovery in Foreign Exchange,” American Economic Review 93(1), 38-62.

Balduzzi, Pierluigi, Edwin J. Elton, and T. Clifton Green, 2001. "Economic News and Bond Prices: Evidence from the U.S. Treasury Market,” Journal of Financial and Quantitative Analysis 36(4), 523-43.

Ball, Lawrence and Niamh Sheridan, 2003. “Does Inflation Targeting Make a Difference?” In: The Inflation Targeting Debate, B. Bernanke and M. Woodford, eds. Chicago: University of Chicago Press.

Bekaert, Geert, Robert J. Hodrick, and David A. Marshall, 2001. "Peso Problem Explanations for Term Structure Anomalies.” Journal of Monetary Economics 48, 241-70.

Bernanke, Ben S., 2004. “The Great Moderation,” speech before the Eastern Economic Association, Washington, DC, February 20, 1994, available at http://www.federalreserve.gov/boarddocs/speeches/2004.

Bernanke, Ben S., Thomas Laubach, Frederic S. Mishkin, and Adam S. Posen, 1999. Inflation Targeting: Lessons from the International Experience. Princeton, NJ: Princeton University Press.

Bernanke, Ben S. and Frederic S. Mishkin, 1997. "Inflation Targeting: A New Framework for Monetary Policy?” Journal of Economic Perspectives 11, 97-116.

Berg, Claes and Richard Grottheim, 1997. “Monetary Policy in Sweden Since 1992,” BIS Policy Papers No. 2: Proceedings of a Conference on Monetary Policy in the Nordic Countries since 1992, available at http://www.bis.org/publ/plcy02.htm.

British Broadcasting Corporation, 1997. "Brown Sets Bank of England Free,” May 6, 1997. As reported on http://news.bbc.co.uk/onthisday/hi/dates/stories/may/6/newsid_3806000/3806313.stm.

Brunner, Allan, 2000. “On the Derivation of Monetary Policy Shocks: Should We Throw the VAR Out with the Bath Water?” Journal of Money, Credit, and Banking 32, 254-79. 
Campbell, John Y. and Robert J. Shiller, 1991. "Yield Spreads and Interest Rate Forecasts: A Bird’s Eye View.” Review of Economic Studies 58, 595-514.

Christiano, Lawrence, Martin Eichenbaum, and Charles Evans, 2005. "Nominal Rigidities and the Dynamic Effects of a Shock to Monetary Policy,” Journal of Political Economy 113, 1-45.

Cochrane, John H. and Monika Piazzesi, 2005. “Bond Risk Premia.” American Economic Review 95(1), 138-60.

The Economist, 1994. “Willkommen Herr Clark.” September 17, 1994, p. 61, anonymous.

Erceg, Christopher and Andrew Levin, 2003. "Imperfect Credibility and Inflation Persistence.” Journal of Monetary Economics 50, 915-944.

Ertürk, Burak and Ümit Özlale, 2005. “Do Inflation Targeting Regimes Affect Inflation Expectations and Uncertainty?” Bilkent University working paper.

Fama, Eugene F. and Robert R. Bliss, 1987. “The Information in Long-Maturity Forward Rates.” American Economic Review 77, 680-92.

The Financial Times, 1994. “U.K. Rates Rise 1/2 \%.” September 13, p. 37.

Gertler, Mark, 2003. Comment on Ball and Sheridan. In: The Inflation Targeting Debate, B. Bernanke and M. Woodford, eds. Chicago: University of Chicago Press.

Gürkaynak, Refet S., 2005. “Using Federal Funds Futures Contracts for Monetary Policy Analysis,” Federal Reserve Board Finance and Economics Discussion Series \#2005-29.

Gürkaynak, Refet S., Brian Sack, and Eric T. Swanson, 2002. “Market-Based Measures of Monetary Policy Expectations.” Federal Reserve Board Finance and Economics Discussion Series \#2002-40.

Gürkaynak, Refet S., Brian Sack, and Eric T. Swanson, 2003. “The Excess Sensitivity of LongTerm Interest Rates: Evidence and Implications for Macroeconomic Models.” Federal Reserve Board Finance and Economics Discussion Series \#2003-50.

Gürkaynak, Refet S., Brian Sack, and Eric T. Swanson, 2005. "The Sensitivity of Long-Term Interest Rates to Economic News: Evidence and Implications for Macroeconomic Models.” American Economic Review 95(1), 425-36.

Gürkaynak, Refet S., Brian Sack, and Jonathan H. Wright, 2005. “The U.S. Treasury Yield Curve.” Unpublished manuscript, Federal Reserve Board, Washington, DC.

Ingersoll, Jonathan E., Jr. and Stephen A. Ross, 1992. "Waiting to Invest: Investment and Uncertainty,” Journal of Business 65(1), 1-29. 
Johnson, David R., 2002. "The Effect of Inflation Targeting on the Behavior of Expected Inflation: Evidence from an 11-Country Panel.” Journal of Monetary Economics 49(8), 1493-1519.

Kozicki, Sharon and Peter A. Tinsley, 2001. "Shifting Endpoints in the Term Structure of Interest Rates,” Journal of Monetary Economics 47, 613-52.

Krueger, Joel T. and Kenneth N. Kuttner, 1996. “The Fed Funds Futures Rate as a Predictor of Federal Reserve Policy.” Journal of Futures Markets 16, 865-79.

Kuttner, Kenneth N., 2001. “Monetary Policy Surprises and Interest Rates: Evidence from the Fed Funds Futures Market.” Journal of Monetary Economics 47, 523-44.

Kuttner, Kenneth N., 2005. “A Snapshot of Inflation Targeting in its Adolescence,” unpublished manuscript, Oberlin College.

Leiderman, L. and Lars E.O. Svensson, eds., 1995. Inflation Targets (London: Centre for Economic Policy Research).

Levin, Andrew and Jeremy Piger, 2002. "Is Inflation Persistence Intrinsic in Industrial Economies?” Federal Reserve Bank of St. Louis Working Paper \#2002-023.

McCallum, Bennett, 1996. "Inflation Targeting in Canada, New Zealand, Sweden, the United Kingdom, and in General.” NBER Working Paper 5579.

Nelson, Charles and Andrew Siegel, 1987. "Parsimonious Modeling of Yield Curves.” Journal of Business 60(4), 473-89.

Orphanides, Athanasios and John C. Williams (2005). "Inflation Scares and Forecast-Based Monetary Policy,” Review of Economic Dynamics 8(2), 498-527.

Persson, Torsten and Guido Tabellini, 1993. "Designing Institutions for Monetary Stability.” Carnegie-Rochester Conference Series on Public Policy 39, 53-84.

Piazzesi, Monika and Eric T. Swanson, 2004. "Futures Prices as Risk-Adjusted Forecasts of Monetary Policy.” NBER Working Paper 10547.

Sack, Brian and Robert Elsasser, 2004. "Treasury Inflation-Indexed Debt: A Review of the U.S. Experience,” Federal Reserve Bank of New York Economic Policy Review, May 2004, 47-63.

Shiller, Robert, John Y. Campbell, and Kermit Schoenholtz, 1983. "Forward Rates and Future Policy: Interpreting the Term Structure of Interest Rates,” Brookings Papers on Economic Activity 1, 173-217.

Svensson, Lars E.O., 1994. "Estimating and Interpreting Forward Interest Rates for Sweden.” Centre for Economic Policy Research Discussion Paper \#1051. 
Svensson, Lars E.O., 1997. "Inflation Forecast Targeting: Implementing and Monitoring Inflation Targets.” European Economic Review 41, 1111-46.

Svensson, Lars E.O. and Michael Woodford, 2003. “Implementing Optimal Policy Through Inflation-Forecast Targeting.” In: The Inflation Targeting Debate, Ben S. Bernanke and Michael Woodford, eds. (Chicago: University of Chicago Press).

Swanson, Eric T., 2006. "Have Increases in Federal Reserve Transparency Improved Private Sector Interest Rate Forecasts?” Journal of Money, Credit, and Banking (forthcoming).

Walsh, Carl, 1995. “Optimal Contracts for Central Bankers.” American Economic Review 85(1), 150-67.

Woodford, Michael, 2003. Interest and Prices: Foundations of a Theory of Monetary Policy (Princeton: Princeton University Press). 